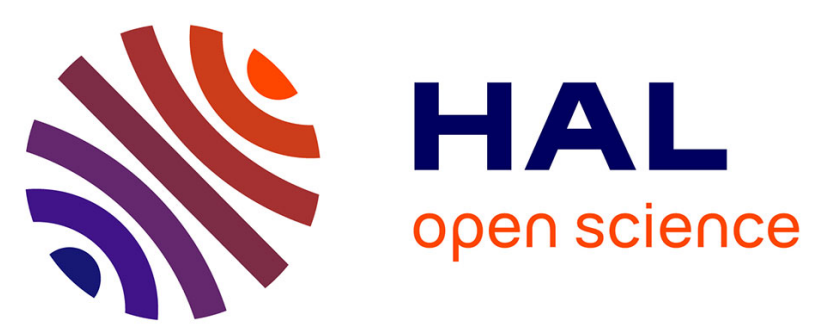

\title{
Bioenergetic modelling of the marine phase of Atlantic salmon (Salmo salar L.)
}

I. Philip Smith, Douglas J. Booker, Neil C. Wells

\section{To cite this version:}

I. Philip Smith, Douglas J. Booker, Neil C. Wells. Bioenergetic modelling of the marine phase of Atlantic salmon (Salmo salar L.). Marine Environmental Research, 2009, 67 (4-5), pp.246. 10.1016/j.marenvres.2008.12.010 . hal-00482198

\section{HAL Id: hal-00482198 \\ https://hal.science/hal-00482198}

Submitted on 10 May 2010

HAL is a multi-disciplinary open access archive for the deposit and dissemination of scientific research documents, whether they are published or not. The documents may come from teaching and research institutions in France or abroad, or from public or private research centers.
L'archive ouverte pluridisciplinaire HAL, est destinée au dépôt et à la diffusion de documents scientifiques de niveau recherche, publiés ou non, émanant des établissements d'enseignement et de recherche français ou étrangers, des laboratoires publics ou privés. 


\section{Accepted Manuscript}

Bioenergetic modelling of the marine phase of Atlantic salmon (Salmo salar L.)

I. Philip Smith, Douglas J. Booker, Neil C. Wells

PII:

S0141-1136(09)00029-4

DOI:

10.1016/j.marenvres.2008.12.010

Reference:

MERE 3322

To appear in:

Marine Environmental Research

Received Date:

22 May 2008

Revised Date:

9 December 2008

Accepted Date:

11 December 2008

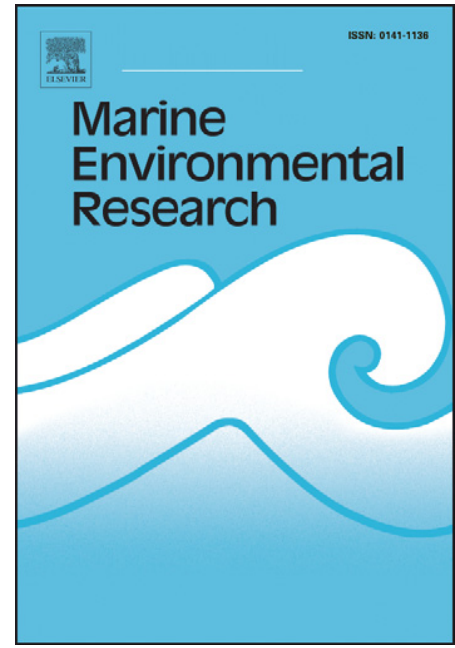

Please cite this article as: Smith, I.P., Booker, D.J., Wells, N.C., Bioenergetic modelling of the marine phase of Atlantic salmon (Salmo salar L.), Marine Environmental Research (2009), doi: 10.1016/j.marenvres.2008.12.010

This is a PDF file of an unedited manuscript that has been accepted for publication. As a service to our customers we are providing this early version of the manuscript. The manuscript will undergo copyediting, typesetting, and review of the resulting proof before it is published in its final form. Please note that during the production process errors may be discovered which could affect the content, and all legal disclaimers that apply to the journal pertain. 
1 Bioenergetic modelling of the marine phase of Atlantic salmon (Salmo salar L.)

2 I. Philip Smith ${ }^{1, *}$, Douglas J. Booker ${ }^{2,4}$, Neil C. Wells ${ }^{3}$

3

4 1. University Marine Biological Station, Millport, Isle of Cumbrae, KA28 0EG, United Kingdom

5 2. Centre for Ecology and Hydrology, Maclean Building, Crowmarsh Gifford, Wallingford,

6 Oxfordshire, OX10 8BB, United Kingdom

7 3. School of Ocean and Earth Science, University of Southampton, National Oceanography

8 Centre, European Way, Southampton, SO14 3ZH, United Kingdom

9 4. Present address: D. J. Booker, National Institute of Water and Atmospheric Research, PO Box 8602, Riccarton, Christchurch 8011, New Zealand

\section{Abstract}

A bioenergetic model of marine-phase, wild Atlantic salmon was constructed to investigate the potential effects on post-smolt growth of predicted changes in oceanic conditions. Short-term estimates of growth in weight were similar to measurements in captivity and simulated growth varied with water temperature and swimming speed as expected. Longer-term estimates of growth in length were less than that achieved by wild salmon, particularly with constant swimming assumed. The model was sensitive to parameters relating to maximum daily food consumption, respiration and the relationships between body energy content, length and weight. Some of the sensitive parameters were based on substantive information on Atlantic salmon and their realistic ranges are likely to be much narrower than those tested. However, other parameter values were based on scant data, farmed Atlantic salmon or other salmonid species, and are therefore less certain and indicate where future empirical research should be focussed.

Keywords: Atlantic salmon, post-smolt, marine phase, growth, temperature, climate change, marine ecology, mathematical models

\section{Introduction}

Populations of Atlantic salmon (Salmo salar L.) have declined considerably across the species' range on both sides of the North Atlantic Ocean since the 1970s (Jonsson and Jonsson, 2004). 
cycle, there are indications of a widespread increase in mortality during the marine phase not attributable to directed fishing (Hawkins, 2000). In most of the well-studied stocks, there has been a 30-year trend of increasing marine mortality in salmon that mature after two or more winters in the sea. Among salmon that mature after only one winter at sea ('grilse'), there appears to have been a sudden increase in marine mortality in the late 1980s, which has persisted subsequently (Potter and Crozier, 2000). Assuming that marine predation on salmon is highest when post-smolts are small (Peterson and Wroblewski, 1984; Griffiths and Harrod, 2007), it seems likely that such significant variation in survival is linked to changes in the nature or intensity of processes operating in the first few weeks after emigration from rivers to the sea. There is mounting evidence that marine mortality of salmon is inversely related to growth rate during the early marine phase and that growth is strongly related to sea temperatures experienced by the fish in that period (Friedland et al., 2005; Peyronnet et al., 2007; McCarthy et al., 2008; Todd et al., 2008).

It is not clear whether the influence of temperature on historical variation in post-smolt growth rate is predominantly a direct effect on salmon physiology or an indirect effect related to ocean currents or prey availability (Hawkins, 2000). Temperature certainly has a direct effect on metabolic processes (Brett and Groves, 1979), but Beaugrand and Reid (2003) have detected significant correlations among indices of climate variability, zooplankton abundance and an index of salmon abundance.

An understanding of how salmon survival may be affected by future changes in oceanic conditions is required to inform management decisions on how best to conserve Atlantic salmon stocks (Solomon et al., 2003). One approach to this is bioenergetic modelling, in which the energy available for somatic growth is estimated from the balance of energy gained from feeding against that lost through egestion, excretion, standard and active metabolism, and reproduction (Brett and Groves, 1979). Combined with a model of how the oceanic ecosystem may respond to climatic changes, this provides a tool for investigating the consequences of future climate scenarios for salmon stocks, as has been done for sockeye salmon (Oncorhynchus nerka) in the north Pacific Ocean (Rand et al., 1997). There have been numerous published bioenergetic models of salmonids, including wild juvenile Atlantic salmon in fresh water (Broekhusien et al., 1994; Elliott and Hurley, 1997; Forseth et al., 2001; Jones et al., 2002; Gurney et al., 2003). Empirical models of growth in relation to temperature, ration and body size have been constructed for marine-phase Atlantic salmon in aquaculture (Austreng et al., 1987; Cho and 
66

67

68

69

70

71

72

73

74

75

76

77

78

79

80

81

82

83

84

85

86

87

88

89

90

91

92

93

94

95

96

Bureau, 1998), but there are no published bioenergetic models of the marine phase of wild $S$. salar.

The aim of the present study was to construct and test an individual-based model (Grimm et al., 1999) of growth in marine-phase Atlantic salmon, using existing information on temperature and body size dependencies of consumption and energy losses. Owing to the limited information on some aspects of the energy metabolism of marine-phase Atlantic salmon, it has been necessary to use parameters estimated for closely-related species or freshwater stages of $S$. salar for some functions. The sensitivity of the model to variation in uncertain parameters has therefore been investigated to indicate where future empirical research effort should be directed. The present model is not spatially explicit (i.e. does not include a representation of varying geographical location), but we have previously reported a model for simulating trajectories of migrating Atlantic salmon (Booker et al., 2008). Coupling these approaches with a climate-driven ecosystem model of the North Atlantic Ocean (e.g. Palmer and Totterdell, 2001) will allow spatially explicit modelling of marine-phase growth.

\section{Methods}

\subsection{Model description}

The model consisted of a system of equations, described below, for calculating daily energy gain and loss from food consumption, egestion, excretion and respiratory losses under different conditions of body size, water temperature, day length, swimming speed and prey availability. Growth was then calculated from the net energy gain. Since the model was not spatially explicit, spatial aspects, such as water temperature, day length and prey density were held constant for each run of the model. The initial salmon body length was taken as $0.125 \mathrm{~m}$ as a typical value for wild smolts (Shearer, 1992; although variation in this value was investigated) and initial weight was calculated from a weight-length relationship derived from unpublished data on smolts from British rivers (I. Russell, G. W. Smith, pers. comm.).

\subsubsection{Prey encounter and capture}

Analysis of stomach contents indicates that salmon prey on a wide variety of invertebrates and fish during their marine phase (Jacobsen and Hansen, 2000). In estuarine and nearshore waters, post-smolts take terrestrial insects and other arthropods, such as intertidal amphipods (Hansen 
97 and Quinn, 1998; Sturlaugsson, 2000). As post-smolts move further offshore, marine prey

98 species become more prevalent and mainly comprise planktonic crustaceans, such as decapod

99 larvae, copepods, amphipods and euphausiids, and larval fish (Sturlaugsson, 2000; Andreassen et

100 al., 2001; Haugland et al., 2006). At oceanic feeding grounds and during the spawning migration,

101 small pelagic fish, such as capelin, sandeels, myctophids and clupeoids, dominate the diet by

102 weight, although in the north-east Atlantic, planktonic crustaceans also constitute a considerable

103 proportion of the diet (Hislop and Shelton, 1993; Holst et al., 1993; Jacobsen and Hansen, 2000,

104 2001). Prey items span a wide range of sizes and energy densities. It has been suggested that

105 salmon are opportunistic feeders, implying a lack of selectivity, although there is some evidence

106 of preference with respect to prey species (Andreassen et al., 2001; Jacobsen and Hansen, 2001)

107 and prey size (Holst et al., 1996; Jacobsen and Hansen, 2001).

108

109 Available prey was modelled as a uniformly distributed constant total biomass per unit volume

110 of sea water, divided proportionally into seven categories for simplicity (Table 1). Average

111 individual mass of prey obtained from published weight-length relationships were used to

112 calculate numerical abundance of each prey category from its biomass. Published values of

113 energy density were used to calculate the energy content of prey items in each category (Table

114 1).

115

116 Salmon were assumed to encounter each category of prey, $i$, within a cylindrical volume of

117 water, $V_{i}\left(\mathrm{~m}^{3}\right)$, defined by swimming speed, $u\left(\mathrm{~m} \mathrm{~s}^{-1}\right)$, the duration of the model time step $(1 \mathrm{~d})$

118 and the salmon's reaction distance - the distance within which they may attack encountered prey

119 items, which can vary by prey category:

120

$$
V_{i}=8.64 \times 10^{4} u \pi d_{i}^{2}
$$

121 The reaction distance, $d_{i}(\mathrm{~m})$, of salmon of length $L_{s}(\mathrm{~m})$ to prey of length $L_{i}(\mathrm{~m}$, Table 1$)$ was

122 calculated using a function given by Hughes and Dill (1990):

$123 \quad d_{i}=120 L_{i}\left(1-e^{\left(-20 L_{s}\right)}\right)$

124 This function indicates that for a given prey length, salmon length has little influence on

125 detection distance when salmon length is $>0.1 \mathrm{~m}$, as is the case for most post-smolts (Shearer, 126 1992). 
128 Following Keeley and Grant (2001), after Wankowski (1979), the range of prey sizes that could

129 be taken was set to $0.012 L_{s}$ to $0.105 L_{s}$. It was assumed that prey width was the limiting

130 dimension and width-length ratios were set for each prey category. The range of prey sizes

131 acceptable to salmon of particular sizes was used to calculate the proportion of each prey

132 category available.

133

134 To calculate the number of prey items potentially eaten within a model time step, a form of the

135 Holling type 2 disc equation (Holling, 1959) was applied, assuming that no more than one prey

136 item can be consumed at a time, salmon can not search for prey while capturing and ingesting

137 ('handling') a prey item and the salmon may not consume every prey item that it encounters. The

138 time spent searching for prey, $t_{\mathrm{s}}(\mathrm{s})$, was given by:

$$
t_{s}=\frac{t_{f}}{1+\left(\sum_{i=1}^{i_{\max }} \rho_{i} V_{i} a_{i} h_{i}\right)}
$$

where $t_{\mathrm{f}}$ is the time available for feeding (set to $12 \mathrm{~h}$ per day in seconds), $i_{\max }$ is the number of prey classes, $\rho_{\mathrm{i}}$ is the density of prey class $i\left(\mathrm{~m}^{-3}\right), a_{\mathrm{i}}$ is the attack rate on prey class $i$ (proportion

142 of encountered prey items taken) and $h_{\mathrm{i}}$ is the handling time for prey class $i$ (s). The potential

143 number of prey items of class $i$ eaten per time step, $n_{\mathrm{i}}$, was given by:

$$
n_{i}=t_{s} a_{i} \rho_{i} V_{i}
$$

145 and the total weight of prey class $i$ potentially consumed per time step, $W_{\mathrm{i}}$ (g), given unlimited 146 stomach size was:

$$
W_{i}=n_{i} w_{i}
$$

148 where $\bar{w}_{i}$ is the average individual weight in prey class $i$ (g). The mean energy density of prey

149 consumed, $\bar{E}\left(\mathrm{~J} \mathrm{~g}^{-1}\right)$, was given by:

150

$$
\bar{E}=\frac{\sum_{i=1}^{i_{\max }}\left(W_{i} E_{i}\right)}{\sum_{i=1}^{i_{\max }} W_{i}}
$$

151 where $E_{\mathrm{i}}$ is the energy density of prey class $i\left(\mathrm{~J} \mathrm{~g}^{-1}\right)$. 
152

153

154

155

156

157

158

159

160

161

162

163

164

165

166

167

168

169

170

171

172

173

174

175

176

177

178

179

\subsubsection{Maximum daily consumption}

Maximum daily consumption, $C_{\max }\left(\mathrm{g} \mathrm{g}^{-1} \mathrm{~d}^{-1}\right)$, was calculated as dry mass of prey per unit dry mass of salmon by a Thornton-Lessem function (Thornton and Lessem, 1978), using the weight exponent of Beauchamp et al. (1989) and fitted to $C_{\max }$ estimates for post-smolt $S$. salar at different temperatures (Handeland et al., 2003; Jørgensen and Jobling, 1994; Damsgård. and Arnesen, 1998; Toften et al., 2003; Stead et al., 1996; Koskela et al., 1997). Iterative non-linear fitting procedures (Wilkinson et al., 1992) failed to converge, so the function was fitted by eye (Table 2).

$C_{\max }$ was converted to maximum wet weight of prey that could be consumed daily, $W_{\text {cmax }}$, using published values of prey species water content (Table 1), water content of salmon from the formula of Johansen et al. (2001), and the body weight of the salmon. Achieved daily consumption, $W_{\mathrm{c}}(\mathrm{g})$, was taken as the lesser of $W_{\mathrm{cmax}}$ and $\sum_{i=1}^{i_{\max }} W_{i}$. Daily ingested energy, $I(\mathrm{~J})$, was the product of $W_{\mathrm{c}}$ and $\bar{E}$. Where $W_{\mathrm{c}}$ was constrained to be $W_{\mathrm{cmax}}$, the number of prey items eaten was recalculated.

\subsubsection{Egestion, excretion and specific dynamic action}

The proportion of ingested energy lost in the faeces, $P_{\mathrm{f}}$, was calculated in relation to water temperature, $T\left({ }^{\circ} \mathrm{C}\right)$, and consumption as a proportion of maximum consumption from:

$$
P_{f}=F_{a} T^{F b 1} e^{F b 2 \frac{W_{c}}{W_{c} \max }}
$$

where $F_{\mathrm{a}}, F_{\mathrm{b} 1}$ and $F_{\mathrm{b} 2}$ are the constant, temperature coefficient and consumption coefficient, respectively, derived for brown trout, Salmo trutta (Elliott, 1976b; Table 3). The proportion of energy lost by excretion was calculated with the same form of relationship using the parameters $U_{\mathrm{a}}, U_{\mathrm{b} 1}$ and $U_{\mathrm{b} 2}$, respectively (Table 3 ).

Specific dynamic action, the additional heat liberated after feeding, can be represented as a constant proportion $\left(P_{\mathrm{SDA}}\right)$ of metabolizable energy (i.e. energy ingested minus energy lost through egestion and excretion) independent of temperature or ration size (Brett and Groves, 1979). A value of $17 \%$ of metabolizable energy was adopted (Nimi and Beamish, 1974). 


\subsubsection{Respiration}

A function relating rate of oxygen consumption $\left(M_{\mathrm{O}_{2}}\right)$ to body weight, swimming speed and temperature derived from measurements of farmed adult Atlantic salmon by Grøttum and Sigholt (1998) was found to produce unrealistic values for small fish and higher swimming speeds. Another function was derived from relationships given by Brett and Glass (1973) for standard and active rates of oxygen consumption in sockeye salmon (Oncorhynchus nerka) as functions of body weight at different temperatures. 'Active' measurements were made at the maximum swimming speed sustained for $1 \mathrm{~h}$ (termed the 'critical' swimming speed, $U_{\text {crit }}$ ). Brett and Glass (1973) also gave temperature-specific relationships between $U_{\text {crit }}$ and body length. Values of $M_{\mathrm{O} 2}$ at intermediate swimming speeds were obtained by interpolating between the standard and active values for the appropriate body weight, temperature and $U_{\text {crit }}$ (Brett and Glass, 1973). In this way, an array of predicted oxygen consumption rates was generated for a range of weights (10, 50, 100, 700 and $2000 \mathrm{~g})$, temperatures $\left(5,15,20^{\circ} \mathrm{C}\right)$ and swimming speeds (body lengths per second, bl s $\left.{ }^{-1}\right)$ as a proportion $(0.2,0.4,0.6,0.8,1.0)$ of $U_{\text {crit. }}$ The weight and temperature increments chosen reflected the conditions under which the relationships of Brett and Glass (1973) had been obtained. Length was calculated from the weight-length relationship given by Brett and Glass (1973). A relationship between rate of oxygen consumption and the independent variables was estimated by multiple regression and found to be of the form:

$$
M_{O_{2}}=3.021 \times 10^{-2} W^{(-0.0068 T+0.0902 U)} 1.1017^{T} 1.6803^{U} 0.9778^{T U}
$$

where, $M_{\mathrm{O} 2}$ is rate of oxygen consumption ( $\left.\mathrm{mg} \mathrm{O}_{2} \mathrm{~g}^{-1} \mathrm{~h}^{-1}\right), W$ is weight $(\mathrm{g}), T$ is temperature $\left({ }^{\circ} \mathrm{C}\right.$ ), and $U$ is swimming speed $\left(\mathrm{bl} \mathrm{s}^{-1}\right)$. The multiple regression was highly significant $\left(F_{5,69}=429.89\right.$, $p<0.0001, r^{2}=0.967$ ), with significant interactions between the effects of weight and temperature, weight and swimming speed, and temperature and swimming speed. The Grøttum and Sigholt (1998) model assumed the effects of these variables were independent.

Comparison of oxygen consumption rates predicted by this function with literature values is not straightfoward, owing to the considerable variation in methodology and conditions in published studies and, in some cases, a lack of information on swimming speed. Nevertheless, oxygen consumption rates predicted by this function were strongly correlated with values reported for $S$. salar at a range of life stages, body sizes, water temperatures and swimming speeds (Withey and Saunders, 1973; Higgins, 1985; Lucas et al., 1993; Lucas, 1994; Maxime, 2002). 
212 The mass of oxygen consumed (mg) was converted to an energy equivalent ( $\mathrm{J}$ ) with an

213 oxycalorific coefficient of $13.563 \mathrm{~J} \mathrm{mg}^{-1}$ (Elliott and Davison, 1975).

214

215 Modelled salmon were assumed to swim at a constant relative speed while migrating

216 ('cruising'), but swam at maximum speed to capture specified prey items ('burst' swimming).

217 Respiration was calculated separately for the proportion of the time that salmon were burst

218 swimming and cruising. Each time a mobile prey item of type $i$ was attacked (determined by

219 prey encounter and attack rates), the salmon was assumed to travel at burst speed for a distance

220 equating to the radius of half of the capture area, $\left(0.5 d_{\mathrm{i}}^{2}\right)^{1 / 2}$. It was assumed that burst swimming

221 was required to capture prey in the 'small fish', 'large fish' and 'squid' categories.

223 Burst swimming speed $\left(u_{\text {burst }}, \mathrm{m} \mathrm{s}^{-1}\right)$ of salmon was calculated in relation to temperature $\left(T,{ }^{\circ} \mathrm{C}\right)$

224 and body length $\left(L_{\mathrm{s}}, \mathrm{m}\right)$ from:

225

$$
u_{\text {burst }}=(0.121 T+5.4525) L_{s}^{(-0.0074 T+0.7009)}
$$

which was derived from equations fitted by Turnpenny et al. (2001) to values reported by

227 Wardle (1975).

\subsubsection{Growth}

229

Assimilated energy $(A, J)$ that was not lost in respiration was assumed to be partitioned into reserves $(Y)$, such as lipids, which may be mobilized to meet metabolic requirements during starvation, and structure $(S)$, which determines body length and can not be mobilized. Following Broekhusien et al. (1994) and Jones et al. (2002), the rate of change in reserves was equal to net assimilation rate $(A)$ minus losses in respiration $(R)$ and the rate of energy commitment to structural tissues:

235

$$
\frac{d Y}{d t}=A-R-\frac{d S}{d t}
$$

The rate of commitment to structure was a variable proportion $(\kappa)$ of the rate of assimilation:

$$
\frac{d S}{d t}=\kappa A
$$


240

241

242

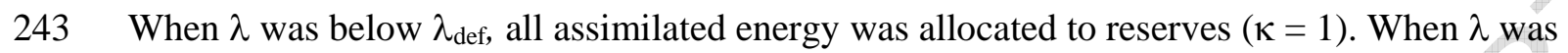

244 above $\lambda_{\text {def }}+\lambda_{\text {switch }}$, the proportion $1-\kappa_{\max }$ of assimilated energy was allocated to reserves.

245

246

247

248

249

250

251

252

253

254

255

256

257

258

259

260

261

262

263

264

265

structural energy should not be lost) and a specified maximum value ( $\left.\kappa_{\max }\right)$ when the reserve/structure ratio lay within a specified range $\left(\lambda_{\text {switch }}\right)$ above the defended level:

$$
\kappa=\frac{\kappa_{\text {max }}\left(\lambda-\lambda_{\text {def }}\right)}{\lambda_{\text {switch }}}, \quad \lambda_{\text {def }} \leq \lambda<\left(\lambda_{\text {def }}+\lambda_{\text {switch }}\right)
$$

Parameter values for the calculation of $\kappa$ are given in Table 4.

Structural and reserve energy content at the start of the next time step were calculated from:

$$
\begin{aligned}
& S_{(t+1)}=S_{t}+\frac{d S}{d t} \\
& Y_{(t+1)}=Y_{t}+\frac{d Y}{d t}
\end{aligned}
$$

Salmon length in the next time step, $L_{\mathrm{s}(\mathrm{t}+1)}$, was given by:

$$
L_{s(t+1)}=L_{0} S^{\alpha}
$$

where $L_{0}$ and $\alpha$ are parameters derived from a re-arrangement of a function relating body energy content to length and weight (Elliott, 1976a; Table 4), applying an estimate of the proportion of body energy content that can not be mobilized during starvation (28.8\%, Jonsson et al., 1997) and substituting for weight with a rearranged weight-length relationship (Broekhuizen et al., 1994).

Body weight in the next time step, $W_{\mathrm{s}(\mathrm{t}+1)}$, was given by:

$$
W_{s(t+1)}=W_{0} L_{s(t+1)}^{\beta}\left(Y_{(t+1)}+S_{(t+1)}\right)^{\gamma}
$$

where $W_{0}, \beta$ and $\gamma$ are parameters derived from a rearrangement of Elliott's (1976a) empirical relationship for total energy as a function of length and wet weight of brown trout, S. trutta (Table 4). Thus, body length depended only on structural energy content, whereas body weight depended on length and total energy content (Jones et al., 2002). Body weight could reduce, but length could not. 
267 To test the sensitivity of the bioenergetic algorithms to variation in their parameters, the model

268

269

270

271

272

273

274

275

276

277

278

279

280

281

282

283

284

285

286

287

288

289

290

291

292

293

294

295

296

297

298 was run with each parameter varied individually between $-50 \%$ and $+50 \%$ of the default values (in $25 \%$ increments), with combinations of a range of constant sea surface temperatures $\left(2-18^{\circ} \mathrm{C}\right.$, by $\left.2^{\circ} \mathrm{C}\right)$ and constant swimming speeds $\left(0.5-2.5 \mathrm{bl} \mathrm{s}^{-1}\right.$, by $\left.0.25 \mathrm{bl} \mathrm{s}^{-1}\right)$. Cotterell and Wardle (2004) measured a maximum sustainable swimming speed of $2.99 \mathrm{bl} \mathrm{s}^{-1}$ for $0.3-\mathrm{m}$ post-smolt Atlantic salmon at $10^{\circ} \mathrm{C}$. Within simulations, available prey density and feeding time were held constant, but variation in these parameters was also investigated between simulations. Other spatial aspects of the model, such as directionality of migration, ocean currents and migratory responses to ocean currents were disregarded. The effects of simple behavioural options in the model were also tested: 'burst' swimming to capture prey, optimising cruising speed (using a constant swimming speed that maximised daily energy gain) and optimising daily cruising duration (salmon swam at a defined speed until maximum daily consumption had been achieved and at a defined minimum speed, $0.05 \mathrm{~m} \mathrm{~s}^{-1}$, for the rest of that day).

Simulated growth under these constant conditions was represented by the length attained after 15.5 months: the average duration of the marine phase for a one-sea-winter salmon emigrating from its home river in early May and returning in mid-August typical of British rivers (unpublished data: FRS, CEFAS). The effect of changes in parameter values has been summarised by the difference in final salmon length between that obtained with a $25 \%$ increase in the default parameter value and that obtained with a $25 \%$ decrease, expressed as a percentage of the final length obtained with the default parameter value.

To compare growth in weight indicated by the model with published measurements of post-smolt growth rate in captivity (progeny of wild parents), simulations were run with fish of the same size and at the same temperature as the empirical studies, with prey attributes set to resemble an excess of the commercially available feed pellets used (moisture content $5 \%$, energy density $24 \mathrm{MJ} \mathrm{kg}^{-1}$, density $1.59 \times 10^{3} \mathrm{~kg} \mathrm{~m}^{-3}$ ). The conditions in two empirical studies were modelled: fish length $0.18 \mathrm{~m}$ and weight $61 \mathrm{~g}$ simulated over a period of $30 \mathrm{~d}$ at $4.3^{\circ} \mathrm{C}, 9.4^{\circ} \mathrm{C}$ or $14.3^{\circ} \mathrm{C}$ (Handeland et al., 1999); and fish length $0.37 \mathrm{~m}$ and weight $528 \mathrm{~g}$ simulated over a period of $84 \mathrm{~d}$ at $9^{\circ} \mathrm{C}$ (Thodesen et al., 1999). Swimming speeds in the published studies were not reported, so simulations were run with speeds of $0.5 \mathrm{bl} \mathrm{s}^{-1}$ and $1.0 \mathrm{bl} \mathrm{s}^{-1}$, which were thought likely to encompass the average values. Specific growth rate (SGR) was calculated as (ln $W_{2}-$ 
299

300

301

302

303

304

305

306

307

308

309

310

311

312

313

314

315

316

317

318

319

320

321

322

323

324

325

326

327

328

329

$\left.\ln W_{1}\right) / \Delta t$, where $W_{1}$ and $W_{2}$ are the simulated body weights (g) at the start and end of a period of $\Delta t$ days (Handeland et al., 1999). Thermal-unit growth coefficient (TGC) was calculated as $\left(W_{2}{ }^{1 / 3}-W_{1}^{1 / 3}\right) / T \Delta t$ (Thodesen et al., 1999), where $T$ is the temperature $\left({ }^{\circ} \mathrm{C}\right)$.

\section{Results}

With the default bioenergetic parameter values, growth varied with sea surface temperature and swimming speed (Fig. 1). At any given temperature, final length was greater at lower swimming speeds, but the effect of swimming speed was less at lower temperatures. At any given swimming speed, final length increased with temperature to a maximum at $14-16^{\circ} \mathrm{C}$ and declined slightly at $18^{\circ} \mathrm{C}$. The effect of temperature on growth was less at higher swimming speeds. The maximum final length with default parameter values was $0.44 \mathrm{~m}$ (at a temperature of $14^{\circ} \mathrm{C}$ and a swimming speed of $0.5 \mathrm{bl} \mathrm{s}^{-1}$ ).

Simulated growth was most sensitive to certain of the parameters directly affecting energy intake (parameters of the function for maximum daily consumption, prey energy density, relative dry weight proportions of salmon and prey), energy expenditure (some of the respiration parameters, burst speed parameters) and the parameters of the length-structure relationship (Table 5, 6).

Certain parameters, mostly powers, led to zero energy reserves ('bioenergetic death') with a 25\% change from the default value: these were the initial weight-length power, maximum consumption parameter $\mathrm{C}_{\mathrm{TL}}$, respiration-temperature coefficient, respiration-temperature-speed coefficient, length-structure power and weight-energy power.

Changes in certain other parameters had a marked effect ( $>10 \%)$ on final length without causing simulated energy reserves to fall to zero (Table 5, 6). In relation to energy intake, for example, growth was positively related to the maximum consumption scale, $C_{\mathrm{A}}$ (Fig. 2a), consumptionweight power, $C_{\mathrm{B}}$ (Fig. 2b), the prey energy density (Fig. 2c) and the salmon dry weight constant, $D W_{\text {a }}$ (Fig. 2d), and was negatively related to the prey dry weight ratio (Fig. 2e). These effects increased with temperature and decreased with swimming speed. Sensitivity to some other parameters was negatively correlated with temperature and swimming speed (e.g. consumption parameter $C_{\mathrm{Q}}$, Fig. 2f). Parameters associated with prey encounter rate and ingestion, such as minimum edible prey size, prey density and reaction distance had less influence on growth (Table 5, 6). At higher temperatures (Table 5) and slower swimming speeds 
330 (Table 6), simulated growth was greater with larger maximum edible prey sizes. Available

331 feeding time and prey item handling time had no effect within the range of values tested.

332

333

334

335

336

337

338

339

340

341

342

343

344

345

346

347

348

349

350

351

352

353

354

355

356

357

358

359

360

361

362

In relation to energy loss, growth was sensitive to parameters of the respiration function (Fig. 3a), with the effects being greater at higher temperatures and swimming speeds. Growth was also sensitive to the burst speed constant (negatively, Fig. 3b) and the burst speed-length-temperature constant (positively, Fig. 3c). Growth was moderately sensitive to parameters of the egestion (Fig. 3d) and excretion functions (Table 5, 6).

In relation to the functions for determining length and weight from assimilated energy, in addition to the high sensitivity to changes in the length-structure power and the weight-energy power mentioned above, growth was sensitive to the length-structure scale (Fig. 4a) and, to a lesser extent, to the maximum proportion of assimilated energy committed to structure ( $\kappa_{\max }$, Fig. $4 \mathrm{~b})$, these effects being positively related to temperature and negatively related to swimming speed. Growth was comparatively insensitive to the defended reserve ratio ( $\left.\lambda_{\text {def }}\right)$ and, at a swimming speed of $1 \mathrm{bl} \mathrm{s}^{-1}$, the weight-length-energy scale $\left(W_{0}\right)$ and the weight-length power ( $\beta$, except at low temperatures). At $10^{\circ} \mathrm{C}$, the influence of the last two parameters varied negatively and positively, respectively, with swimming speed (Table 6). The allocation switch width ( $\left.\lambda_{\text {switch }}\right)$ had no effect within the range of values tested.

For most parameters to which growth showed marked sensitivity, the differences in final length varied monotonically with temperature and swimming speed over the range of values tested. However, with certain parameters, there was an inflection in sensitivity within the tested range of temperatures, including the maximum consumption parameter $C_{\mathrm{TO}}$, (Fig. 5), the burst speedlength-temperature constant, $\kappa_{\max }$ and the length-structure scale.

The implementation of burst swimming to catch nektonic prey items caused a slight reduction in growth, particularly at combinations of high temperatures and low cruising speed (i.e. conditions of maximum growth; Fig. 6). Optimising daily cruising duration resulted in growth being higher and largely independent of cruising speed, particularly when compared with higher continuous cruising speeds (Fig. 7). The percentage improvement in growth over that at given continuous cruising speeds was almost constant across the temperature range, except at higher speeds, when the improvement in growth increased over the lowest temperatures (Fig. 8). Optimising cruising 
363 speed produced almost identical results, since salmon encountered sufficient prey items to

364 achieve their maximum daily consumption even at the minimum speed.

365

366 With prey attributes set to resemble commercial pelleted feed and initial body weight of $61 \mathrm{~g}$

367 (Handeland et al., 2003), modelled values of SGR at swimming speeds of $0.5 \mathrm{bl} \mathrm{s}^{-1}$ and $1.0 \mathrm{bl} \mathrm{s}^{-1}$

368 bracketed the published empirical value for $4.3^{\circ} \mathrm{C}$, but was slightly less than the published

369 values at higher temperatures (Table 7). The modelled TGC for a fish of $528 \mathrm{~g}$ at $9.0^{\circ} \mathrm{C}$

370 swimming at $0.5 \mathrm{bl} \mathrm{s}^{-1}$ was close to the published value (Table 7).

\section{4. Discussion}

372 The maximum salmon length attained over a simulated 15.5-month period with the default

373 parameters $(0.44 \mathrm{~m})$ was somewhat smaller than the typical size of one-sea-winter salmon in UK

374 rivers (e.g. mean length of $0.66 \mathrm{~m}$ in the Chester Dee, CEFAS, unpublished data). The constancy

375 of temperature, prey density, swimming speed and available feeding time in the non-spatial

376 simulation was not intended to represent the seasonally varying conditions experienced by real

377 salmon (although some of the simulated values may reflect annual averages in the ocean), so the

378 absolute values of the final lengths attained can not be expected to be realistic. In particular,

379 salmon are unlikely to swim continuously at a constant speed for 24 hours per day over

380 prolonged periods, but there is, as yet, little information on swimming speeds during marine

381 migration and at oceanic feeding grounds. Ultrasonic tracking of post-smolts in the early stages

382 of marine migration has indicated rapid movement during both day and night, with speeds over

383 the ground of 0.1 to $>0.5 \mathrm{~m} \mathrm{~s}^{-1}$ and a strong tidal component to speed and direction (Holm et al.,

384 2003). However, tagged post-smolts recaptured in the Faroe-Shetland Channel 38-56 days after

385 release from their home rivers in Ireland had been displaced at speeds of $0.2-0.3 \mathrm{~m} \mathrm{~s}^{-1}$ - slower

386 than the Slope Current in which they were found (Holst et al., 2000). Observations of farmed

387 salmon in sea cages have shown a variety of sustained swimming speeds and diel patterns of

388 speed, ranging from minimum speeds of $<0.5 \mathrm{bl} \mathrm{s}^{-1}$ to maximum daily values of $1.0-1.5 \mathrm{bl} \mathrm{s}^{-1}$

389 (Sutterlin et al., 1979; Kadri et al., 1991; Juell and Westerberg, 1993; Smith et al., 1993; Andrew

390 et al., 2002). In the present model, modifying the behaviour of simulated salmon to optimise

391 swimming speed, or to swim at minimum speed after the maximum daily consumption had been

392 achieved, led to more realistic growth rates, particularly when higher swimming speeds would

393 otherwise have applied. Comparison of modelled rates of growth in weight over shorter periods

394 with available published values for progeny of wild parents indicated good agreement under 
395

396

397

398

399

400

401

402

403

404

405

406

407

408

409

410

411

412

413

414

415

416

417

418

419

420

421

422

423

424

425

426

427

428

some conditions and underestimates in others (Thodesen et al., 1999; Handeland et al., 2003). Without knowing the swimming speeds in the empirical studies it is not possible to account for the differences.

Under the default bioenergetic parameters, the optimal temperature for growth was $14-16{ }^{\circ} \mathrm{C}$. This optimum arises from the different temperature dependencies of maximum daily consumption, which peaks at $17-18{ }^{\circ} \mathrm{C}$, and respiration, which increases exponentially with temperature. From rather sparse data on Norwegian farmed strains of Atlantic salmon postsmolts, Handeland et al. (2003) estimated that the optimum temperature for growth was $13^{\circ} \mathrm{C}$. A wild strain grew faster at $14{ }^{\circ} \mathrm{C}$ (the maximum temperature tested) than at $9{ }^{\circ} \mathrm{C}$ or $4{ }^{\circ} \mathrm{C}$ (Handeland et al., 2003). Koskela et al. (1997) estimated an optimum temperature for growth in large juvenile Baltic salmon (Salmo salar, $16-29 \mathrm{~cm}$ total length) of $16^{\circ} \mathrm{C}$.

Simulated growth declined with increasing swimming speed, due to the additional energy used in active metabolism. Empirical studies have produced mixed results about the effects of exercise on growth rate in Atlantic salmon (Davison, 1997). In some studies, growth rate was higher under moderate exercise regimes (Totland et al., 1987; Jørgensen and Jobling, 1993), owing to greater appetite, utilisation of feed (Jørgensen and Jobling, 1993) and perhaps release of growth hormones (Barrett and McKeown, 1988). However, these results are difficult to interpret in the present context, because the low swimming speeds in these studies involved holding salmon together in still or slow-flowing water, leading to greater stress from agonistic activity, which may have depressed appetite and increased the metabolic rate.

Output from the model was very sensitive to the values of certain parameters, so it is important to consider their likely range of values. For some of these parameters, a 25\% change may have resulted in unrealistic values. For example, the initial weight-length power was varied to extremes of 2.3 and 3.8, whereas the $95 \%$ confidence limit of this parameter derived from over 6500 measurements of Atlantic salmon from the British Isles (CEFAS and FRS, unpublished data) was 3.02 to 3.03 (analysis in present study). Over a range of 2.8 to 3.2 (i.e. $-7 \%$ to $+7 \%$ ), there was little effect on final length.

The length-structure power, weight-energy power and weight-length power were derived from a combination of information from Atlantic salmon (weight-length relationship and maximum energy loss during starvation) and brown trout (Salmo trutta; a function relating body energy 
429 density to length and weight). There may therefore be greater uncertainty about the value of 430 these parameters and, given their importance to the model, an energy-length-weight relationship derived for post-smolt Atlantic salmon would be helpful, but difficult to obtain for wild fish.

432

Output from the present model was also very sensitive to maximum consumption parameter $C_{\mathrm{TL}}$, which contributes to defining the temperature dependence of daily food consumption at higher temperatures. In the Thonton-Lessem function for maximum daily consumption, four of the parameters define temperatures at which consumption is certain proportions of the maximum (Table 2). Paradoxical results may be obtained if these temperatures are out of sequence, as may have occurred by varying one of them independently of the others. Other parameters of the maximum daily consumption function also had a strong influence on the output. The parameters were fit to data on Atlantic salmon fed on fish meal pellets under controlled conditions, but there are few data for post-smolts below $8{ }^{\circ} \mathrm{C}$ and above $14{ }^{\circ} \mathrm{C}$. There is therefore scope for studying food consumption of wild post-smolts fed on natural prey over a range of temperatures, although it is not easy to keep wild fish healthy in captivity or to supply natural prey.

Not surprisingly, simulated growth was sensitive to certain other parameters directly affecting energy intake: prey energy density and the relative dry weight proportions of salmon and prey. The relative dry matter contents of salmon and prey are important because maximum consumption is calculated first on the basis of dry weight of prey per unit dry weight of salmon. The wet weight of prey is then calculated from the ratio of the proportions of dry weight in prey and salmon. Water content of salmon and prey species is variable, but the values chosen are thought to represent average conditions. Prey energy density varies seasonally and spatially among and within species, but again, the values chosen were considered to be representative.

Parameters associated with prey encounter rate and ingestion, such as minimum edible prey size, prey density, reaction distance, available feeding time and prey item handling time had little 456 influence on growth within the range of values tested. Under most conditions tested, simulated salmon were able to achieve their maximum daily consumption. However, in the North Atlantic Ocean, prey density and available feeding time will vary by more than the plus or minus 50\% differences tested here. The influence of prey abundance and distribution can be investigated by coupling bioenergetic, migration and ecosystem models. 
462 Values of the parameters in the respiration function had a strong negative influence on simulated 463 growth, particularly the respiration-temperature coefficient and the respiration-temperaturespeed coefficient, which both led to bioenergetic death when increased by $25 \%$. However, all of the respiration parameters had important effects on simulated growth, which is not surprising, given that respiration is the major energy loss. The respiration function was derived from relationships given by Brett and Glass (1973) for standard and active rates of oxygen consumption in sockeye salmon (Oncorhynchus nerka). Although the predictions from this function compared reasonably well with the limited available measurements of Atlantic salmon, it would be worthwhile to conduct a detailed study of metabolic rate in marine-phase Atlantic salmon in relation to body size, temperature and swimming speed, so that respiratory losses can

472 be modelled more reliably.

473

474 Level of activity is one of the most uncertain aspects of bioenergetic modelling of salmon during 475 the marine phase. There is a pressing need to extend empirical studies of swimming activity from 476 estuarine and coastal waters to offshore areas during both migration and non-migratory periods 477 in oceanic feeding grounds. In the meantime, spatially explicit modelling provides insights into 478 the consequences of different migratory behaviours (Booker et al., 2008).

\section{Conclusions}

481 An individual-based bioenergetic model has been developed to estimate variation in marine 482 growth, and indirectly survival, of Atlantic salmon in relation to smolt body size, sea water 483 temperature, prey availability and swimming activity. Short-term estimates of growth in weight 484 were similar to empirical measurements made in captivity; longer-term estimates of growth in 485 length were more difficult to assess, owing to uncertainty about the oceanic conditions 486 experienced by wild salmon and their patterns of swimming activity. The non-spatial model is 487 sensitive to certain physiological parameters for which there is limited information available for 488 wild, marine-phase Salmo salar and this highlights areas for future empirical research. When coupled with an ecosystem model of the North Atlantic Ocean, the present bioenergetic model will allow the effects of future changes in oceanic conditions on the growth and survival of

491 Atlantic salmon to be investigated. 


\section{Acknowledgements}

493 This study was funded by the UK Department for Environment, Food and Rural Affairs (contract

494 no. SF0237). P. Ward helped to gather information on salmon prey and A. Moore (Cefas)

495 provided helpful advice. The following are thanked for making unpublished data available: G.W.

496 Smith (Fisheries Research Services), I. Davidson and R. Cove (Environment Agency), I. Russel

497 (Cefas), A. Ibbotson (Centre for Ecology and Hydrology), N. Jonsson (Norwegian Institute for

498 Nature Research), W. Roy (University of Stirling).

499

\section{References}

501

502

503

504

505

506

507

508

509

510

511

512

513

514

515

516

Andreassen, P.M.R., Martinussen, M.B., Hvidsten, N.A., Stefansson, S.O., 2001. Feeding and prey-selection of wild Atlantic salmon post-smolts. Journal of Fish Biology 58, 1667-1679.

Andrew, J.E., Noble, C., Kadri, S., Jewell, H., Huntingford, F.A., 2002. The effect of demand feeding on swimming speed and feeding responses in Atlantic salmon Salmo salar L., gilthead sea bream Sparus aurata L. and European sea bass Dicentrarchus labrax L. in sea cages. Aquaculture Research 33, 501-507.

Arkhipkin, A.I., Bjørke, H., 1999. Ontogenetic changes in morphometric and reproductive indices of the squid Gonatus fabricii (Oegopsida, Gonatidae) in the Norwegian Sea. Polar Biol 22, 357-365.

Austreng, E., Storebakken, T., Åsgård, T., 1987. Growth rate estimates for cultured Atlantic salmon and rainbow trout. Aquaculture 60, 157-160.

Båmstedt, U., 1986. Chemical composition and energy content. In: Corner, E.D.S., O’Hara, S.C.M. (Eds.), The biological chemistry of marine copepods. Clarendon Press, Oxford, pp. $1-58$.

Barrett, B.A., McKeown, B.A., 1988. Sustained exercise increases plasma growth hormone concentrations in two anadromous salmonids. Canadian Journal of Fisheries and Aquatic Sciences 45, 747-749.

Beauchamp, D.A., Stewart, D.J., Thomas, G.L., 1989. Corroboration of a bioenergetics model for sockeye salmon. Transactions of the American Fisheries Society 118, 597-607.

Beaugrand, G., Reid, P.C., 2003. Long-term changes in phytoplankton, zooplankton and salmon related to climate. Global Change Biology 9, 801-817. 
522

523

524

525

526

527

528

529

530

531

532

533

534

535

536

537

538

539

540

541

542

543

544

545

546

547

548

549

550

551

Booker, D.J., Wells, N.C., Smith, I.P., 2008. Modelling the trajectories of migrating Atlantic salmon, Salmo salar L. Canadian Journal of Fisheries and Aquatic Sciences 65, 352-361.

Brett, J.R., Glass, N.R., 1973. Metabolic rates and critical swimming speeds of sockeye salmon (Oncorhynchus nerka) in relation to size and temperature. Journal of the Fisheries Research Board of Canada 30, 379-387.

Brett, J.R., Groves, T.D.D., 1979. Physiological energetics. In: Hoar, W.S., Randall, D.J., Brett, J.R. (Eds.), Fish physiology. Vol. 8. Bioenergetics and growth. Academic Press, New York, pp. 279-352.

Broekhuizen, N., Gurney, W.S.C., Jones, A., Bryant, A.D., 1994. Modeling compensatory growth. Functional Ecology 8, 770-782.

Cho, C.Y., Bureau, D.P., 1998. Development of bioenergetic models and the Fish-PrFEQ software to estimate production, feeding ration and waste output in aquaculture. Aquatic Living Resources 11, 199-210.

Clarke, M.R., 1966. A review of the systematics and ecology of oceanic squids. Advances in Marine Biology 4, 91-300.

Cotterell, S.P., Wardle, C.S., 2004. Endurance swimming of diploid and triploid Atlantic salmon. Journal of Fish Biology 65, 55-68.

Damsgård, B., Arnesen, A.M., 1998. Feeding, growth and social interactions during smolting and seawater acclimation in Atlantic salmon, Salmo salar L. Aquaculture 168, 7-16.

Davison, W., 1997. The effects of exercise training on teleost fish, a review of recent literature. Comparative Biochemistry and Physiology 117A, 67-75.

Elliott, J.M., 1976. Energy losses in the waste products of brown trout (Salmo trutta L.). Journal of Animal Ecology 45, 561-580.

Elliott, J.M., 1976. Body composition of brown trout (Salmo trutta L.) in relation to temperature and ration size. Journal of Animal Ecology 45, 273-289.

Elliott, J.M., Davison, W., 1975. Energy equivalents of oxygen consumption in animal energetics. Oecologia 19, 195-201.

Elliott, J.M., Hurley, M.A., 1997. A functional model for maximum growth of Atlantic Salmon parr, Salmo salar, from two populations in northwest England. Functional Ecology 11, 592603. 
552 Forseth, T., Hurley, M.A., Jensen, A.J., Elliott, J.M., 2001. Functional models for growth and

553

554

555

556

557

558

559

560

561

562

563

564

565

566

567

568

569

570

571

572

573

574

575

576

577

578

579

580

581 food consumption of Atlantic salmon parr, Salmo salar, from a Norwegian river. Freshwater Biology 46, 173-186.

Friedland, K.D., Chaput, G., MacLean, J.C., 2005. The emerging role of climate in post-smolt growth of Atlantic salmon. ICES Journal of Marine Science 62, 1338-1349.

Griffiths, D., Harrod, C., 2007. Natural mortality, growth parameters, and environmental temperature in fishes revisited. Canadian Journal of Fisheries and Aquatic Sciences 64, 249-255.

Grimm, V., Wyszomirski, T., Aikman, D., Uchmanski, J., 1999. Individual-based modelling and ecological theory: synthesis of a workshop. Ecological Modelling 115, 275-282.

Grøttum, J.A., Sigholt, T., 1998. A model for oxygen consumption of Atlantic salmon (Salmo salar) based on measurements of individual fish in a tunnel respirometer. Aquacultural Engineering 17, 241-251.

Gurney, W.S.C., Jones, W., Veitch, A.R., Nisbet, R.M., 2003. Resource allocation, hyperphagia, and compensatory growth in juveniles. Ecology 84, 2777-2787.

Handeland, S.O., Björnsson, B.T., Arnesen, A.M., Stefansson, S.O., 2003. Seawater adaptation and growth of post-smolt Atlantic salmon (Salmo salar) of wild and farmed strains. Aquaculture 220, 367-384.

Hansen, L.P., Quinn, T.P., 1998. The marine phase of the Atlantic salmon (Salmo salar) life cycle, with comparisons to Pacific salmon. Canadian Journal of Fisheries and Aquatic Sciences 55, 104-118.

Haugland, M., Holst, J.C., Holm, M., Hansen, L.P., 2006. Feeding of Atlantic salmon (Salmo salar L.) post-smolts in the Northeast Atlantic. ICES Journal of Marine Science 63, 14881500.

Hawkins, A.D., 2000. Problems facing salmon in the sea - summing up. In: Mills, D. (Ed.), The ocean life of Atlantic salmon: environmental and biological factors influencing survival. Fishing News Books, Oxford, pp. 211-221.

Hayward, P.J., Ryland, J.S. (Eds.), 1995. Handbook of the marine fauna of north-west Europe. Oxford University Press, Oxford.

Head, R.N., Harris, R.P., Bonnet, D., Irigoien, X., 1999. A comparative study of size-fractioned 
582

583

584

585

586

587

588

589

590

591

592

593

594

595

596

597

598

599

600

601

602

603

604

605

606

607

608

609

610

611

612

mesozooplankton biomass and grazing in the North East Atlantic. Journal of Plankton Research 21, 2285-2308.

Hewett, S.W., Johnson, B.L., 1987. A generalized bioenergetics model of fish growth for microcomputers. Technical Report WIS-SG-87-245. University of Wisconsin Sea Grant Institute, Madison, Wisconsin.

Higgins, P.J., 1985. Metabolic differences between Atlantic salmon (Salmo salar) parr and smolts. Aquaculture 45, 33-53.

Hislop, J.R.G., Shelton, R.G.J., 1993. Marine predators and prey of Atlantic salmon (Salmo salar L.). In: Mills, D.H. (Ed.), Salmon in the sea and new enhancement strategies. Fishing News Books, Oxford, pp. 104-118.

Holland, D.J., 1978. Lipid reserves and energy metabolism in the larvae of benthic marine invertebrates. In: Malins, D.C., Sargent, J.R. (Eds.), Biochemical and biophysical perspectives in marine biology, Vol. 4. Academic Press, London, pp. 85-123.

Holling, C.S., 1959. Some characteristics of simple types of predation and parasitism. Canadian Entomologist 91, 385-398.

Holm, M., Holst, J.C., Hansen, L.P., Jacobsen, J.A., O’Maoiléidigh, N., Moore, A., 2003. Migration and distribution of Atlantic salmon post-smolts in the North Sea and North-East Atlantic. In: Mills, D. (Ed.), Salmon at the edge. Blackwell Science, Oxford, pp. 7-23.

Holst, J.C., Hansen, L.P., 1996. Observations of abundance, stock composition, body size and food of postsmolts of Atlantic salmon in the NE Atlantic during summer. International Council for the Exploration of the Sea CM 1996/M:4, 1-15.

Holst, J.C., Nilsen, F., Hodneland, K., Nylund, A., 1993. Observations of the biology and parasites of postsmolt Atlantic salmon, Salmo salar, from the Norwegian sea. Journal of Fish Biology 42, 962-966.

Holst, J.C., Shelton, R., Holm, M., Hansen, L.P., 2000. Distribution and possible migration routes of post-smolt Atlantic salmon in the north-east Atlantic. In: Mills, D. (Ed.), The ocean life of Atlantic salmon: environmental and biological factors influencing survival. Fishing News Books, Oxford, pp. 65-74.

Hughes, N.F., Dill, L.M., 1990. Position choice by drift-feeding salmonids: model and test for Arctic grayling (Thymallus arcticus) in subarctic mountain streams, Interior Alaska. Canadian Journal of Fisheries and Aquatic Sciences 47, 2039-2048. 
613 Jacobsen, J.A., Hansen, L.P., 2000. Feeding habits of Atlantic salmon at different life stages at 614 sea. In: Mills, D. (Ed.), The ocean life of Atlantic salmon. Environmental and biological 615 factors influencing survival. Fishing News Books, Oxford, pp. 170-192.

616 Jacobsen, J.A., Hansen, L.P., 2001. Feeding habits of wild and escaped farmed Atlantic salmon, 617 Salmo salar L., in the Northeast Atlantic. ICES Journal of Marine Science 58, 916-933. 618 Johansen, S.J.S., Ekli, M., Stangnes, B., Jobling, M., 2001. Weight gain and lipid deposition in 619 Atlantic salmon, Salmo salar, during compensatory growth: evidence for lipostatic 620 regulation? Aquaculture Research 32, 963-974.

621 Jones, W., Gurney, W.S., Speirs, D.C., Bacon, P.J., Youngson, A.F., 2002. Seasonal patterns of 622 growth, expenditure and assimilation in juvenile Atlantic salmon. Journal of Animal $623 \quad$ Ecology 71, 916-924.

624 Jonsson, B., Jonsson, N., 2004. Factors affecting marine production of Atlantic salmon (Salmo 625 salar). Canadian Journal of Fisheries and Aquatic Sciences 61, 2369-2383.

626 Jonsson, N., Jonsson, B., Hansen, L.P., 1997. Changes in proximate composition and estimates 627 of energetic costs during upstream migration and spawning in Atlantic salmon Salmo salar. 628 Journal of Animal Ecology 66, 425-436.

Jørgensen, E.H., Jobling, M., 1993. The effects of exercise on growth, food utilisation and osmoregulatory capacity of juvenile Atlantic salmon, Salmo salar. Aquaculture 116, 233-

Jørgensen, E.H., Jobling, M., 1994. Feeding and growth of exercised and unexercised juvenile Atlantic salmon in freshwater, and performance after transfer to seawater. Aquaculture International 2, 154-164.

Juell, J.-E., Westerberg, H., 1993. An ultrasonic telemetry system for automatic positioning of individual fish used to track Atlantic salmon (Salmo salar L.) in a sea cage. Aquacultural Engineering 12, 1-18.

Kadri, S., Metcalfe, N.B., Huntingford, F.A., Thorpe, J.E., 1991. Daily feeding rhythms in Atlantic salmon in sea cages. Aquaculture 92, 219-224.

640 Keeley, E.R., Grant, J.W.A., 2001. Prey size of salmonid fishes in streams, lakes, and oceans. 641 Canadian Journal of Fisheries and Aquatic Sciences 58, 1122-1132.

642 Koskela, J., Pirhonen, J., Jobling, M., 1997. Feed intake, growth rate and body composition of 
643

644

645

646

647

648

649

650

651

652

653

654

655

656

657

658

659

660

661

662

663

664

665

666

667

668

669

670

671

672

juvenile Baltic salmon exposed to different constant temperatures. Aquaculture International 5, 351-360.

Logerwell, E.A., Schaufler, L.E., 2005. New data on proximate composition and energy density of Steller sea lion (Eumetopias jubatus) prey fills seasonal and geographic gaps in existing information. Aquatic Mammals 31, 62-82.

Lucas, M.C., 1994. Heart rate as an indicator of metabolic rate and activity in adult Atlantic salmon, Salmo salar. Journal of Fish Biology 44, 889-903.

Lucas, M.C., Johnstone, A.D.F., Tang, J., 1993. An annular respirometer for measuring aerobic metabolic rates of large, schooling fishes. Journal of Experimental Biology 175, 325-331.

Marshall, S.M., Orr, A.P., 1955. The biology of a marine copepod Calanus finmarchicus (Gunnerus). Oliver \& Boyd, Edinburgh.

Mauchline, J., 1980. The biology of euphausiids. Advances in Marine Biology 18, 373-637.

Mauchline, J., 1998. The biology of calanoid copepods. Advances in Marine Biology 33, 1-701.

Maxime, V., 2002. Effects of transfer to sea water on standard and routine metabolic rates in smolting Atlantic salmon at different stages of seawater adaptability. Journal of Fish Biology 61, 1423-1432.

McCarthy, J.L., Friedland, K.D., Hansen, L.P., 2008. Monthly indices of the post-smolt growth of Atlantic salmon from the Drammen River, Norway. Journal of Fish Biology 72, 15271588.

Newell, G.E., Newell, R.C., 1977. Marine plankton: a practical guide, 5th edn. Hutchinson \& Co. Ltd, London.

Niimi, A.J., Beamish, F.W.H., 1974. Bioenergetics and growth of largemouth bass (Micropterus salmoides) in relation to body weight and temperature. Canadian Journal of Zoology 52, $447-456$.

Palmer, J.R., Totterdell, I.J., 2001. Production and export in a global ocean ecosystem model. Deep-Sea Research Part I - Oceanographic Research Papers 48, 1169-1198.

Payne, S.A., Johnson, B.A., Otto, R.S., 1999. Proximate composition of some north-eastern Pacific forage fish species. Fisheries Oceanography 8, 159-177.

Peterson, I., Wroblewski, J.S., 1984. Mortality rate of fishes in the pelagic ecosystem. Canadian Journal of Fisheries and Aquatic Sciences 41, 1117-1120. 
673 Peyronnet, A., Friedland, K.D., Maoileidigh, N.O., Manning, M., Poole, W.R., 2007. Links

674

675

676

677

678

679

680

681

682

683

684

685

686

687

688

689

690

691

692

693

694

695

696

697

698

699

700

701

702

703 between patterns of marine growth and survival of Atlantic salmon Salmo salar, L. Journal of Fish Biology 71, 684-700.

Potter, E.C.E., Crozier, W.W., 2000. A perspective on the marine survival of Atlantic salmon. In: Mills, D. (Ed.), The ocean life of Atlantic salmon: environmental and biological factors influencing survival. Fishing News Books, Oxford, pp. 19-36.

Rand, P.S., Scandol, J.P., Walter, E.E., 1997. NerkaSim: a research and educational tool to simulate the marine life history of Pacific salmon in a dynamic environment. Fisheries Research 22, 6-13.

Shearer, W.M., 1992. The Atlantic salmon. Natural history, exploitation and future management. Halsted Press, John Wiley \& Sons, Inc., New York.

Shelton, R.G.J., Turrell, W.R., Macdonald, A., McLaren, I.S., Nicoll, N.T., 1997. Records of post-smolt Atlantic salmon, Salmo salar L., in the Faroe-Shetland Channel in June 1996. Fisheries Research 31, 159-162.

Smith, I.P., Metcalfe, N.B., Huntingford, F.A., Kadri, S., 1993. Daily and seasonal patterns in the feeding behaviour of Atlantic salmon (Salmo salar L.) in a sea cage. Aquaculture 117, 165-178.

Solomon, D.J., Mawle, G.W., Duncan, W., 2003. An integrated approach to salmonid management. Fisheries Research 62, 229-234.

Stead, S.M., Houlihan, D.F., McLay, H.A., Johnstone, R., 1996. Effect of ration and seawater transfer on food consumption and growth of Atlantic salmon (Salmo salar) smolts. Canadian Journal of Fisheries and Aquatic Science 53, 1030-1037.

Sturlaugsson, J., 2000. The food and feeding of Atlantic salmon (Salmo salar L.) during feeding and spawning migrations in Icelandic coastal waters. In: Mills, D. (Ed.), The ocean life of Atlantic salmon. Environmental and biological factors influencing survival. Fishing News Books, Oxford, pp. 193-210.

Sutterlin, A., Jokola, K.J., Holte, B., 1979. Swimming behavior of salmonid fishes in ocean pens. Journal of the Fisheries Research Board of Canada 36, 948-954.

Thodesen, J., Grisdale-Helland, G., Helland, S., Gjerde, B., 1999. Feed intake, growth and feed utilization of offspring from wild and selected Altantic salmon (Salmo salar). Aquaculture 180, 237-246. 
704

705

706

707

708

709

710

711

712

713

714

715

716

717

718

719

720

721

722

723

724

725

726

727

728

729

Thornton, K.W., Lessem, A.S., 1978. A temperature algorithm for modifying biological rates. Transactions of the American Fisheries Society 107, 284-287.

Todd, C.D., Hughes, S.L., Marshall, C.T., MacLean, J.C., Lonergan, M.E., Biuw, E.M., 2008. Detrimental effects of recent ocean surface warming on growth conditions of Atlantic salmon. Global Change Biology 14, 958-970.

Toften, H., Arnesen, A.M., Jobling, M., 2003. Feed intake, growth and ionoregulation in Atlantic salmon (Salmo salar L.) smolts in relation to dietary addition of a feeding stimulant and time of seawater transfer. Aquaculture 217, 647-662.

Totland, G.K., Kryvi, H., Jødestøl, K.A., Christiansen, E.N., Tangerås, A., Slinde, E., 1987. Growth and composition of the swimming muscle of adult Atlantic salmon (Salmo salar L.) during long-term sustained swimming. Aquaculture 66, 299-313.

Turnpenny, A.W.H., Blay, S.R., Carron, J.J., Clough, S.C., 2001. Literature review swimming speeds in fish. R \& D Technical Report W2-026/TR2. Environment Agency, Bristol, 45 pp.

Van Pelt, T.I., Piatt, J.F., Lance, B.K., Roby, D.D., 1997. Proximate composition and energy density of some north Pacific forage fishes. Comparative Biochemistry and Physiology 118A, 1393-1398.

Wankowski, J.W.J., 1979. Morphological limitations, prey size selectivity, and growth response of juvenile atlantic salmon, Salmo salar. Journal of Fish Biology 14, 89-100.

Wardle, C.S., 1975. Limit of fish swimming speed. Nature 225, 725-727.

Wheeler, A., 1978. Key to the fishes of Northern Europe. A guide to the identification of more than 350 species. Frederick Warne \& Co., Ltd., London.

Wilkinson, L., Hill, M., Welna, J.P., Birkenbeuel, G.K., 1992. Systat for Windows: Statistics, Version 5 Edition. Systat Inc., Evanston, Illinois.

Withey, K.G., Saunders, R.L., 1973. Effect of a reciprocal photoperiod regime on standard rate of oxygen consumption of postsmolt Atlantic salmon (Salmo salar). Journal of the Fisheries Research Board of Canada 30, 1898-1900. 


\section{Figure legends}

731 Figure 1 Contours of final salmon length (m) as a function of sea surface temperature and

732 swimming speed with default bioenergetic parameter values.

733

734 Figure 2 Contours of final salmon length (m) as a function of sea surface temperature and the

735 value of certain parameters of the growth model: (a) maximum consumption scale (constant),

$736 \quad C_{\mathrm{A}}$; (b) maximum consumption-weight exponent, $C_{\mathrm{B}}$; (c) prey energy density; (d) salmon dry

737 weight proportion scale, $D W_{\text {a }}$; (e) proportional dry matter content of prey; (f) maximum

738 consumption parameter $C_{\mathrm{Q}}$ - the low temperature $\left({ }^{\circ} \mathrm{C}\right)$ at which maximum daily consumption is

739 a defined proportion (default 0.25 ) of the value at the optimum temperature (Hewett and

740 Johnson, 1987). Swimming speed $1 \mathrm{bl} \mathrm{s}^{-1}$ in all cases.

741

742 Figure 3 Contours of final salmon length (m) as a function of sea surface temperature and the

743 value of certain parameters of the growth model: (a) respiration scale; (b) burst speed constant;

744 (c) burst speed-length-temperature constant; (d) egestion scale (a proportion). Swimming speed

$7451 \mathrm{bl} \mathrm{s}^{-1}$ in all cases. Crosses indicate combinations of parameters under which energy reserves

746 reached zero during the simulation.

747

748 Figure 4 Contours of final salmon length $(\mathrm{m})$ as a function of sea surface temperature and the

749 value of certain parameters of the growth model: (a) length-structure scale; (b) maximum

750 proportion of assimilated energy commited to structure, $\kappa_{\max }$. Swimming speed $1 \mathrm{bl} \mathrm{s}^{-1}$ in all

751 cases. Crosses indicate combinations of parameters under which energy reserves reached zero

752 during the simulation.

753

754 Figure 5 Contours of final salmon length (m) as a function of sea surface temperature and value

755 of the maximum consumption parameter $C_{\mathrm{TO}}$, at a swimming speed of $1 \mathrm{bl} \mathrm{s}^{-1}$. $C_{\mathrm{TO}}$ is the

756 temperature $\left({ }^{\circ} \mathrm{C}\right)$ below the optimum temperature at which maximum daily consumption is 0.98

757 of the value at the optimum (Hewett and Johnson, 1987).

758

759 Figure 6 Final salmon length (m) as a function of sea surface temperature and swimming speed

760 with (black contours) or without (grey contours) burst swimming to capture nektonic prey items. 
762 Figure 7 Final salmon length $(\mathrm{m})$ as a function of sea surface temperature and swimming speed

763 with (black contours) or without (grey contours) optimising the duration of cruise swimming by

764 swimming at a specified minimum speed after maximum daily consumption had been achieved.

765

766 Figure 8 Contours of the percentage increase in final length achieved by optimising the duration

767 of cruise swimming, as a function of sea surface temperature and the swimming speed.

768

769

770

771

772 


\section{Table legends}

774 Table 1. Attributes of prey categories.

775

776

Table 2. Parameter values for the Thornton-Lessem function fitted to maximum daily

777 consumption estimates for post-smolt Salmo salar (symbols after Hewett and Johnson, 1987).

778

779

780

781

782

783

784 785

786

787

788

789

790

791

792

793

794

795

796

797

798

799

800

801

802

Table 3. Parameter values for the function relating the proportion of ingested energy lost through egestion or nitrogenous excretion as a function of water temperature and consumption as a proportion of the maximum daily consumption.

Table 4. Parameter values of functions for allocation of assimilated energy to reserves or structure, calculation of length from structure and calculation of weight from length and reserves.

Table 5. Sensitivity of simulation results to variation in the model parameters at different sea surface temperatures and a swimming speed of $1 \mathrm{bl} \mathrm{s}^{-1}$. Difference in final salmon length between that obtained with a $25 \%$ increase in the default parameter value and that obtained with a $25 \%$ decrease, expressed as a percentage of the final length obtained with the default parameter value. Asterisks indicate cases in which the simulated salmon reached zero energy reserves (bioenergetic 'death') during simulations with altered parameter values.

Table 6. Sensitivity of simulation results to variation in the model parameters at different swimming speeds and a sea surface temperature of $10^{\circ} \mathrm{C}$. Difference in final salmon length between that obtained with a $25 \%$ increase in the default parameter value and that obtained with a $25 \%$ decrease, expressed as a percentage of the final length obtained with the default parameter value. Asterisks indicate cases in which the simulated salmon reached zero energy reserves (bioenergetic 'death') during simulations with altered parameter values.

Table 7. Comparison of simulated and published values of specific growth rate (SGR) and thermal-unit growth coefficient (TGC) under different conditions of initial body weight, temperature and swimming speed. 
803

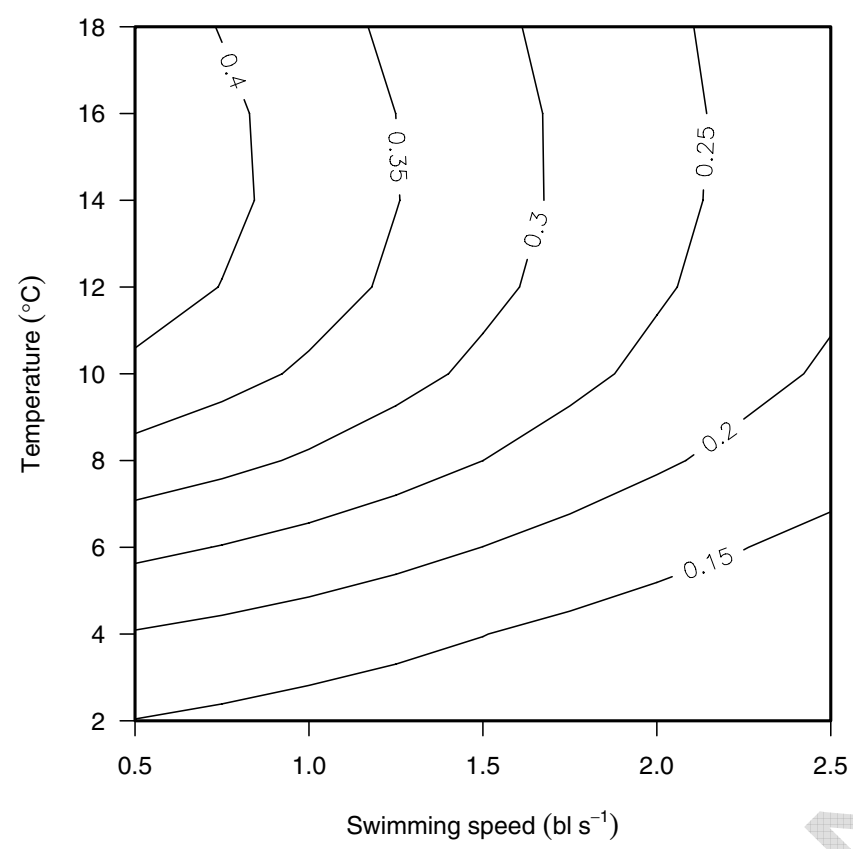

804

805

806 Fig 1 
807
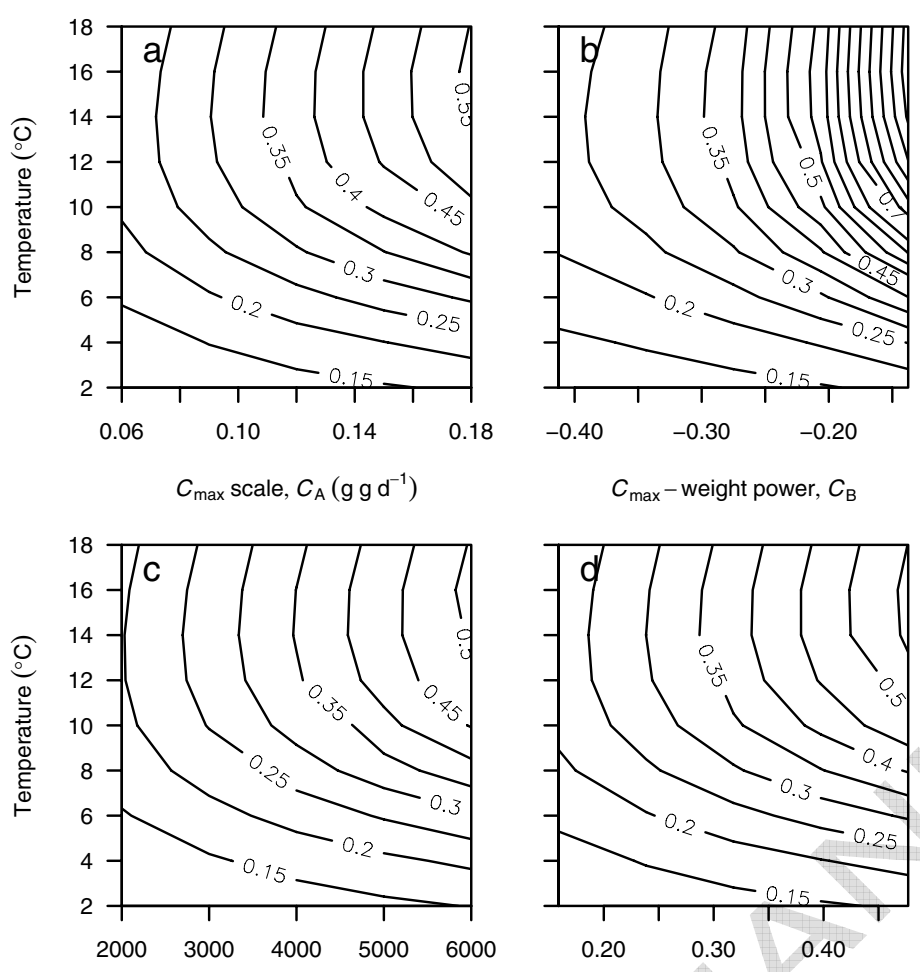

$C_{\max }-$ weight power, $C_{\mathrm{B}}$

Prey energy density $\left(\mathrm{J} \mathrm{g}^{-1}\right)$

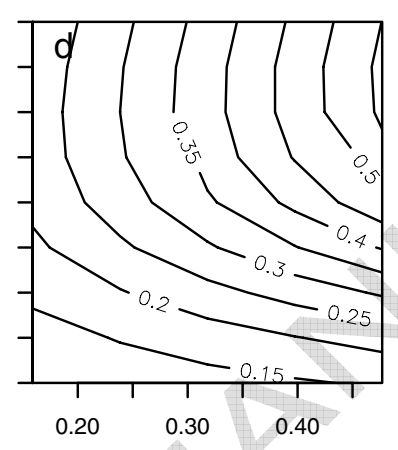

Salmon dry wt prop. constant, $\mathrm{DW}_{\mathrm{a}}$
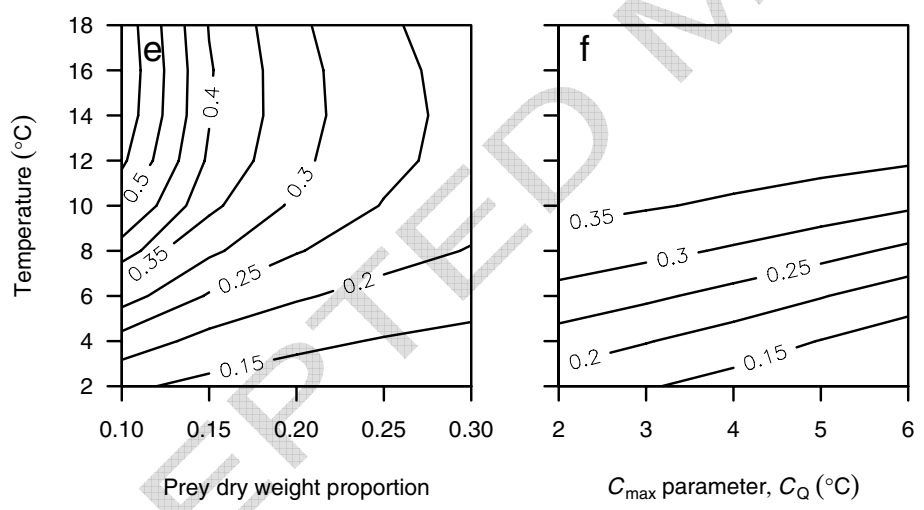

808

809

$810 \quad$ Fig 2 
811

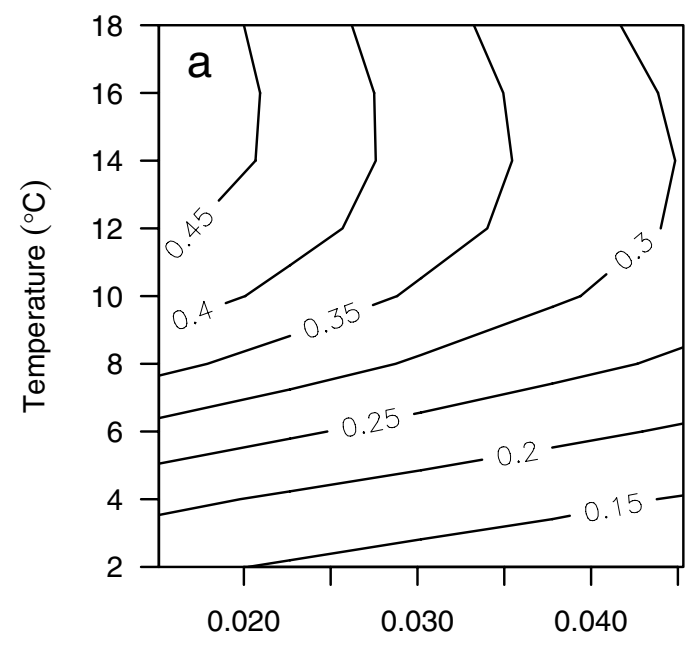

Respiration scale, $R_{\mathrm{A}}\left(\mathrm{mg} \mathrm{O}_{2} \mathrm{~kg}^{-1} \mathrm{~h}^{-1}\right)$

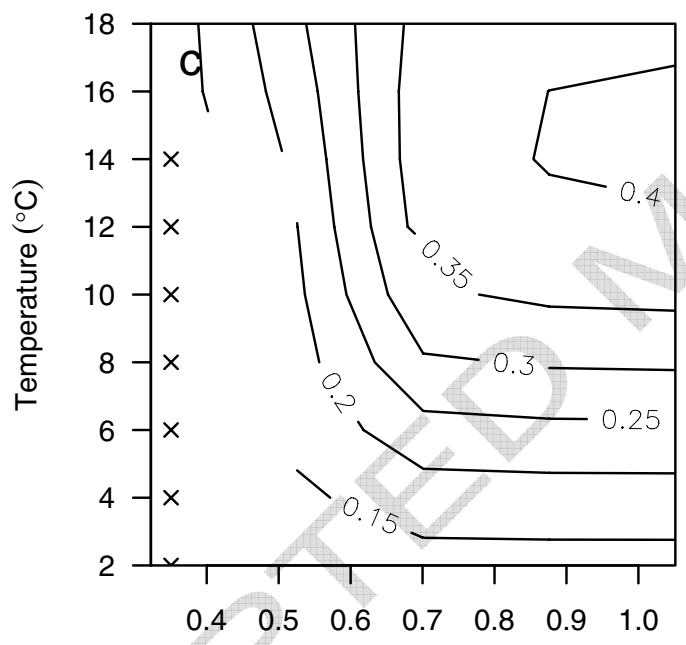

Burst speed-length-temperature constant, $a_{\text {burst-LT }}$

812 $\left(\mathrm{m} \mathrm{s}^{-1}\right)$

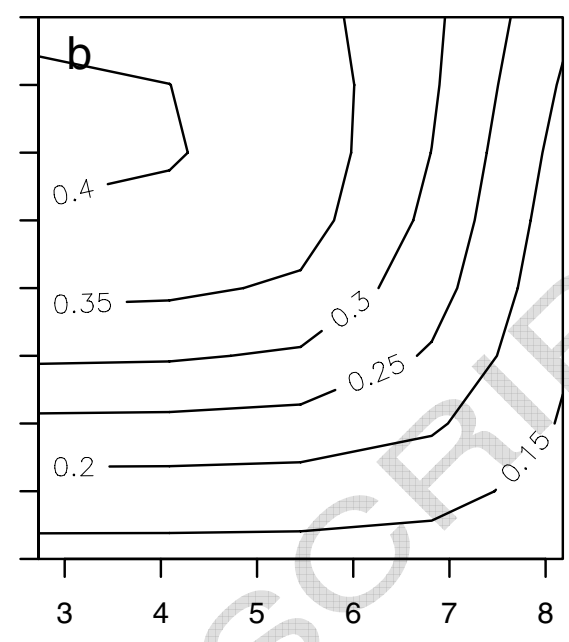

Burst speed constant, $a_{\text {burst }}\left(\mathrm{m} \mathrm{s}^{-1}\right)$

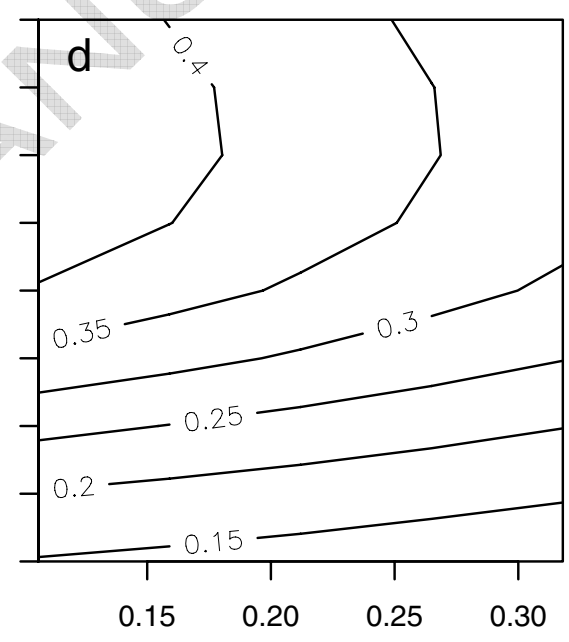

Egestion scale, $F_{\mathrm{A}}$

813

$814 \quad$ Fig 3 
815
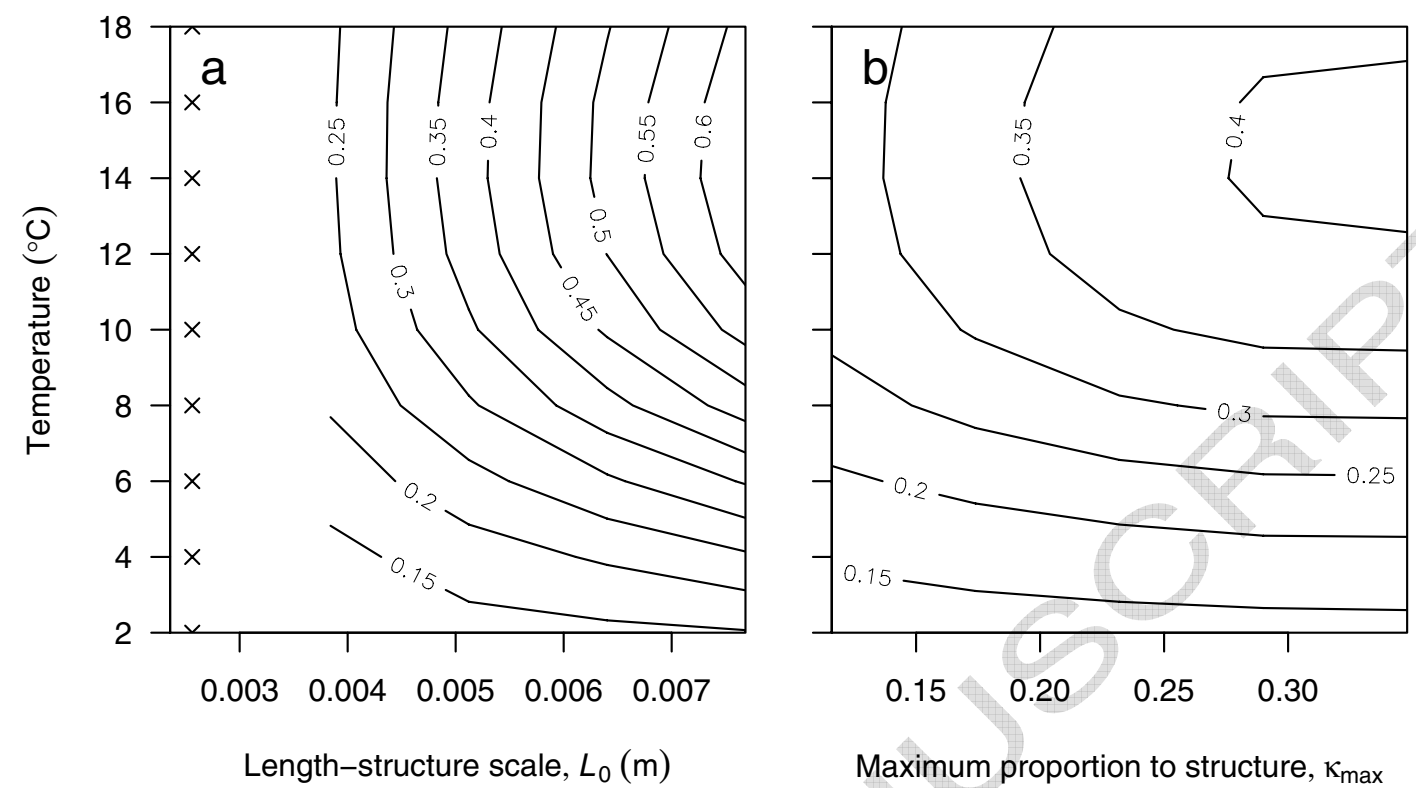

Maximum proportion to structure, $\kappa_{\max }$

816

817

$818 \quad$ Fig 4 
819

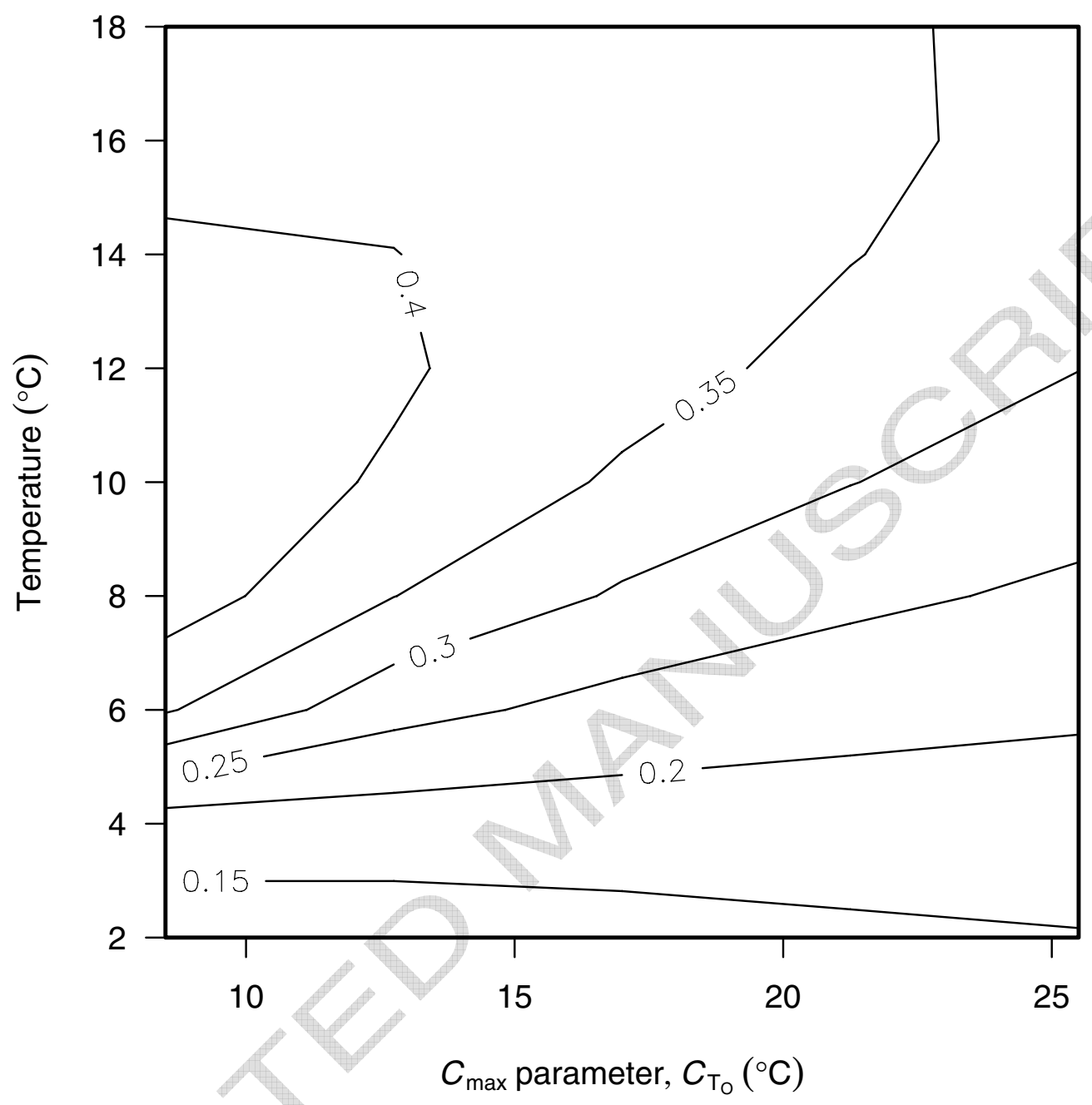

820

821

$822 \quad$ Fig 5 
823

824 Fig 6

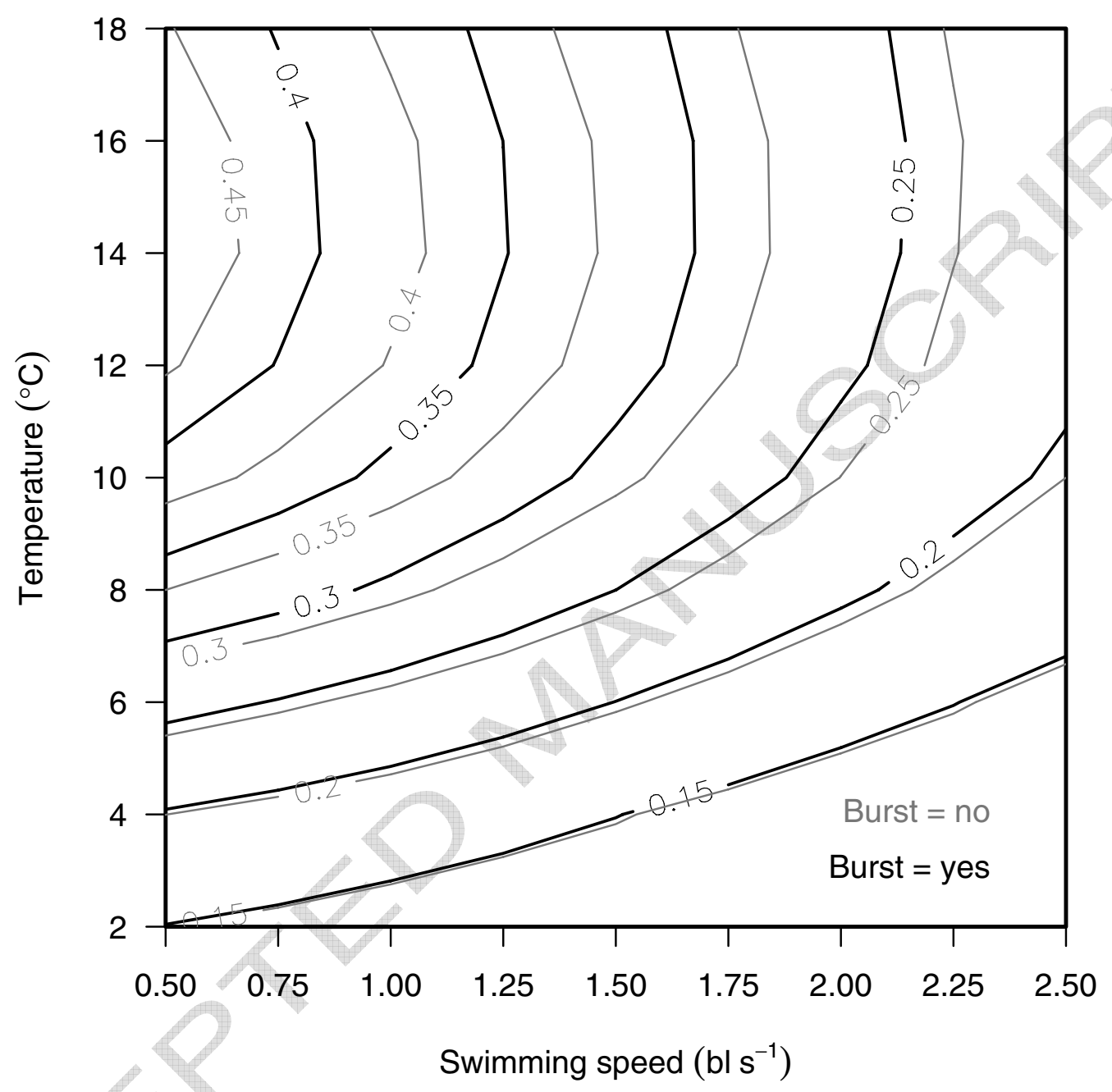

825 
826

827

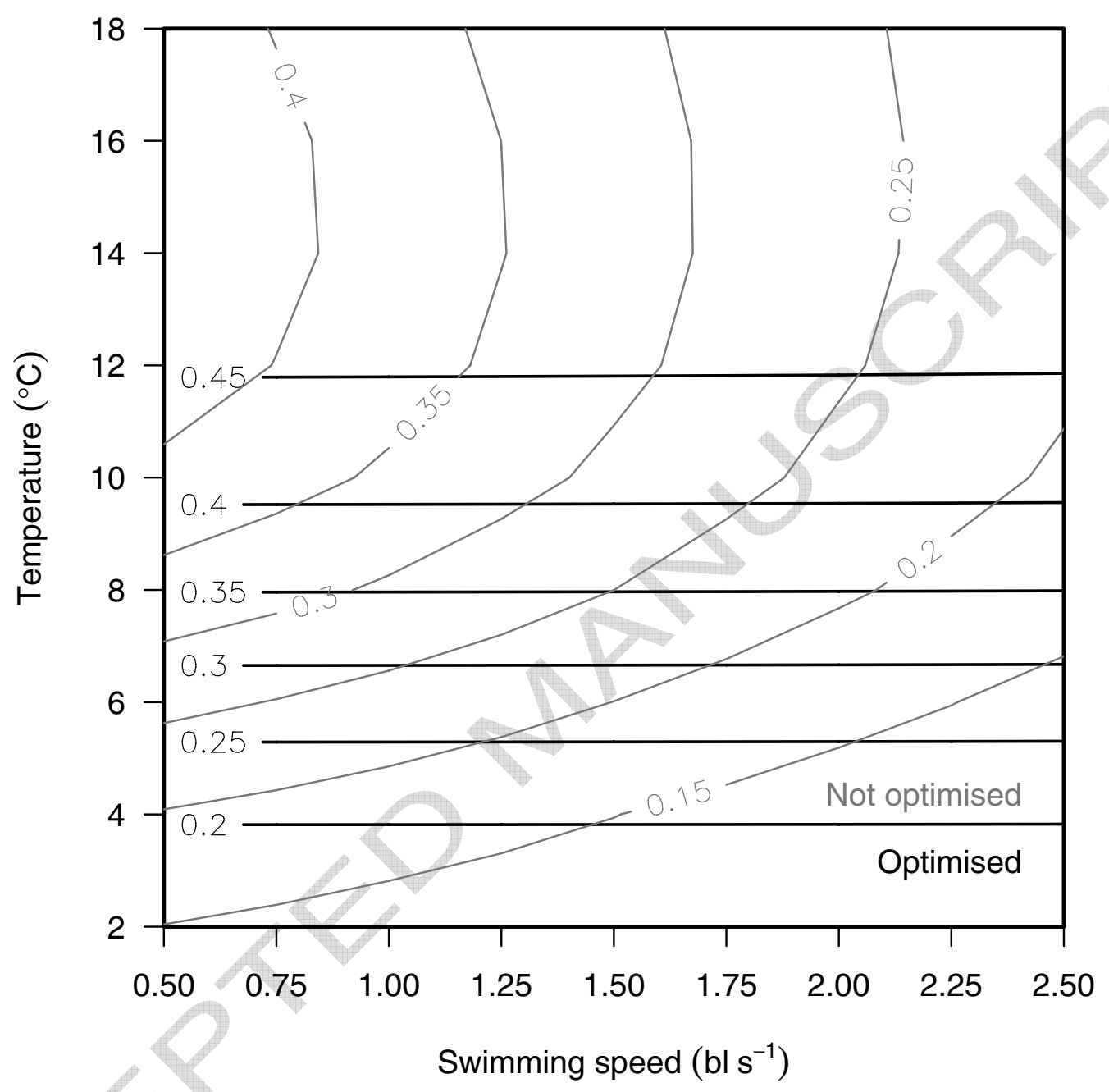

828

$829 \quad$ Fig 7 


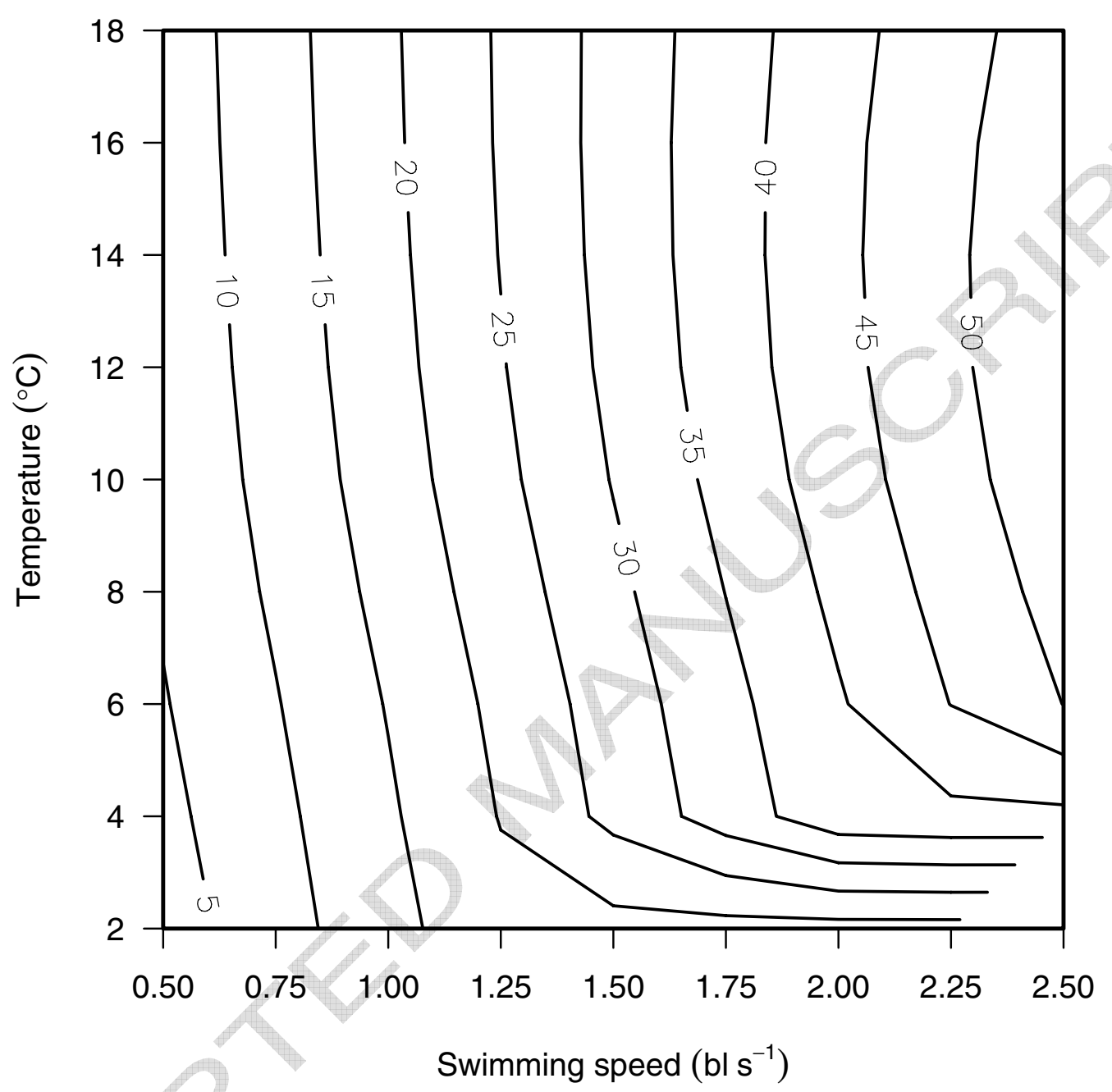

831

832

$833 \quad$ Fig 8 
Table 1. Attributes of prey categories.

\begin{tabular}{|c|c|c|c|c|c|c|c|}
\hline Prey category & $\begin{array}{c}1 \\
\text { 'nauplii' }\end{array}$ & $\begin{array}{c}2 \\
\text { 'small } \\
\text { copepods' }\end{array}$ & $\begin{array}{c}3 \\
\text { 'large } \\
\text { copepods' }\end{array}$ & $\begin{array}{c}4 \\
\text { ‘euphausiids' }\end{array}$ & $\begin{array}{c}5 \\
\text { ‘small } \\
\text { fish’ }\end{array}$ & $\begin{array}{c}6 \\
\text { ‘larger } \\
\text { fish’ }\end{array}$ & $\begin{array}{c}7 \\
\text { ‘squid' }\end{array}$ \\
\hline Energy density $\left(\mathrm{J} \mathrm{g}^{-1}\right)$ & $4000^{\mathrm{a}}$ & $5000^{b}$ & $5000^{b}$ & $3800^{c}$ & $5000^{\mathrm{d}}$ & $6000^{\mathrm{d}}$ & $3900^{\mathrm{d}}$ \\
\hline Minimum size (m) & $2 \times 10^{-4} \mathrm{a}$ & $5 \times 10^{-4 b}$ & $1 \times 10^{-3 b}$ & $2 \times 10^{-3 c}$ & $2 \times 10^{-2} \mathrm{e}$ & $10^{-2}$ & $2 \times 10^{-2 \mathrm{f}}$ \\
\hline Maximium size (m) & $5 \times 10^{-4 a}$ & $1 \times 10^{-3}$ & $3.5 \times 10^{-3}$ & $4 \times 10^{-2 c}$ & $6 \times 10^{-2 e}$ & $\times 10^{-1 \mathrm{e}}$ & $2 \times 10^{-1 \mathrm{f}}$ \\
\hline Shape (L:W) & $1.75^{\mathrm{g}}$ & $3.24^{\mathrm{h}}$ & $3.24^{\mathrm{h}}$ & $5.88^{\mathrm{C}}$ & $6.00^{\mathrm{e}}$ & $6.00^{\mathrm{e}}$ & $2.63^{\mathrm{f}, \mathrm{i}}$ \\
\hline $\begin{array}{l}\text { Weight-length } \\
\text { constant }\left(\mathrm{g} \mathrm{m}^{-b}\right)\end{array}$ & $\begin{array}{l}2.565 \\
\times 10^{4 j}\end{array}$ & $\begin{array}{l}2.565 \\
\times 10^{4 j}\end{array}$ & $\begin{array}{l}2.565 \\
\times 10^{4 j}\end{array}$ & $\begin{array}{l}1.663 \\
\times 10^{3 c}\end{array}$ & $\begin{array}{l}8.103 \\
\times 10^{3 \mathrm{~d}}\end{array}$ & $\begin{array}{l}8.103 \\
\times 10^{3 \mathrm{~d}}\end{array}$ & $\begin{array}{l}2.805 \\
\times 10^{3 \mathrm{k}}\end{array}$ \\
\hline $\begin{array}{l}\text { Weight-length } \\
\text { power, } b\end{array}$ & $2.919^{\mathrm{j}}$ & $2.919^{\mathrm{j}}$ & $2.919^{\mathrm{j}}$ & $2.70^{\mathrm{C}}$ & $2.98^{\mathrm{d}}$ & $2.98^{\mathrm{d}}$ & $2.4589^{k}$ \\
\hline Water content (\%) & $80^{\mathrm{a}}$ & $80^{\mathrm{j}}$ & $80^{\mathrm{j}}$ & 80 & $78^{\mathrm{d}, \mathrm{l}, \mathrm{m}}$ & $74^{\mathrm{d}, \mathrm{l}, \mathrm{m}}$ & $80^{\mathrm{d}, \mathrm{m}}$ \\
\hline Prey fractions ${ }^{\mathrm{n}}$ & 0.58 & 0.27 & 0.15 & 0.3 & 0.25 & 0.1 & 0.15 \\
\hline
\end{tabular}

Sources: a. Holland (1978); b. Båmstedt (1986); c. Mauchline (1980); d. Van Pelt et al. (1997); e. Wheeler (1978); f. Clarke (1966); g. Newell and Newell (1977); h. Marshall and Orr (1955); i. Hayward and Ryland (1995); j. Mauchline (1998); k. Arkhipkin and Bjørke (1999); l. Payne et al. (1999); m. Logerwell and Schaufler (2005); n. Head et al. (1999) 
Table 2. Parameter values for the Thornton-Lessem function fitted to maximum daily consumption estimates for post-smolt Salmo salar (symbols after Hewett and Johnson, 1987).

\begin{tabular}{lc}
\hline Parameter & Value \\
\hline Scale, $C_{\mathrm{A}}\left(\mathrm{g} \mathrm{g}^{-1} \mathrm{~d}^{-1}\right)$ & 0.12 \\
Weight exponent, $C_{\mathrm{B}}$ & -0.275 \\
Ascending limb lower temperature dependence, $C_{\mathrm{K} 1}$ & 0.25 \\
Descending limb lower temperature dependence, $C_{\mathrm{K} 4}$ & 0.75 \\
Ascending limb lower temperature, $C_{\mathrm{Q}},\left({ }^{\circ} \mathrm{C}\right)$ & 4 \\
Ascending limb upper temperature, $C_{\mathrm{TO}},\left({ }^{\circ} \mathrm{C}\right)$ & 17 \\
Descending limb lower temperature, $C_{\mathrm{TM}},\left({ }^{\circ} \mathrm{C}\right)$ & 18 \\
Descending limb upper temperature, $C_{\mathrm{TL}},\left({ }^{\circ} \mathrm{C}\right)$ & 24 \\
\hline
\end{tabular}


Table 3. Parameter values for the function relating the proportion of ingested energy lost through egestion or nitrogenous excretion as a function of water temperature and consumption as a proportion of the maximum daily consumption.

\begin{tabular}{|c|c|c|c|}
\hline Parameter & Egestion & \multicolumn{2}{|c|}{ Excretion } \\
\hline Constant & $\begin{array}{ll}F_{\mathrm{a}} & 0.212\end{array}$ & $U_{\mathrm{a}}$ & 0.026 \\
\hline Temperature & -0.222 & $U_{\mathrm{b} 1}$ & 0.580 \\
\hline Proportion of max. consumption & 0.631 & $U_{\mathrm{b} 2}$ & -0.299 \\
\hline
\end{tabular}


Table 4. Parameter values of functions for allocation of assimilated energy to reserves or structure, calculation of length from structure and calculation of weight from length and reserves.

\begin{tabular}{ll}
\hline Parameter & \multicolumn{1}{c}{ Value } \\
\hline Defended reserve ratio, $\lambda_{\text {def }}$ & 2.44 \\
Allocation switch width, $\lambda_{\text {switch }}$ & 0.362 \\
Maximum proportion to structure, $\kappa_{\max }$ & 0.232 \\
Length-structure scale, $L_{0}(\mathrm{~m})$ & $3.621 \times 10^{-3}$ \\
Length-structure power, $\alpha$ & 0.341 \\
Weight-length-energy scale, $W_{0}(\mathrm{~g})$ & $2.0072 \times 10^{-2}$ \\
Weight-length power, $\beta$ & 0.692 \\
Weight-energy power, $\gamma$ & 0.719 \\
\hline
\end{tabular}


Table 5. Sensitivity of simulation results to variation in the model parameters at different sea surface temperatures and a swimming speed of $1 \mathrm{bl} \mathrm{s}^{-1}$. Difference in final salmon length between that obtained with a 25\% increase in the default parameter value and that obtained with a $25 \%$ decrease, expressed as a percentage of the final length obtained with the default parameter value. Asterisks indicate cases in which the simulated salmon reached zero energy reserves (bioenergetic 'death') during simulations with altered parameter values.

\begin{tabular}{|c|c|c|c|c|c|c|c|c|c|}
\hline \multirow{2}{*}{ Parameter } & \multicolumn{9}{|c|}{ Sea surface temperature $\left({ }^{\circ} \mathrm{C}\right)$} \\
\hline & 2 & 4 & 6 & 8 & 10 & 12 & 14 & 16 & 18 \\
\hline Initial fish length & 28.5 & 15.6 & 10.9 & 8.4 & 7.3 & 6.8 & 6.5 & 6.4 & 6.3 \\
\hline Initial weight-length scale & -1.7 & 1.5 & 2.1 & 1.9 & 1.8 & 1.7 & 1.7 & 1.6 & 1.6 \\
\hline Initial weight-length power & $*$ & $*$ & $*$ & $*$ & $*$ & $*$ & $*$ & * & * \\
\hline Minimum swimming speed & -3.1 & -2.4 & -1.9 & -1.6 & -1.4 & -1.4 & -1.4 & -1.5 & -1.6 \\
\hline Maximum swimming speed & 0.0 & 0.0 & 0.0 & 0.0 & 0.0 & 0.0 & 0.0 & 0.0 & 0.0 \\
\hline Minimum edible prey size & 0.0 & 0.0 & -0.1 & -0.2 & -0.2 & -0.2 & -0.2 & -0.3 & -0.3 \\
\hline Maximum edible prey size & 0.1 & 0.2 & 1.1 & 3.3 & 5.9 & 7.4 & 8.0 & 8.0 & 7.4 \\
\hline Zooplankton density & -0.7 & -1.2 & -1.5 & -1.4 & -1.0 & -0.9 & -0.9 & -0.9 & -0.9 \\
\hline Zooplankton 'lost' to higher predators & 0.0 & -0.1 & -0.1 & -0.1 & -0.1 & -0.1 & -0.1 & -0.1 & -0.1 \\
\hline Reaction distance scale, $D_{\text {a }}$ & -0.3 & -0.7 & -1.5 & -2.5 & -3.3 & -3.6 & -3.8 & -3.7 & -3.4 \\
\hline Reaction distance power, $D_{\mathrm{b}}$ & 0.1 & 0.1 & 0.1 & 0.1 & 0.1 & 0.1 & 0.1 & 0.1 & 0.1 \\
\hline Prey handling time & 0.0 & 0.0 & 0.0 & 0.0 & 0.0 & 0.0 & 0.0 & 0.0 & 0.0 \\
\hline Maximum consumption scale, $C_{\mathrm{A}}$ & 15.4 & 27.1 & 32.6 & 37.1 & 40.9 & 43.5 & 45.2 & 46.5 & 47.5 \\
\hline Maximum consumption parameter, $C_{\mathrm{B}}$ & 15.6 & 28.3 & 40.4 & 53.0 & 63.9 & 70.5 & 74.1 & 76.4 & 77.8 \\
\hline Maximum consumption parameter, $C_{\mathrm{Q}}$ & -21.7 & -30.9 & -24.5 & -15.5 & -7.9 & -3.2 & -1.0 & -0.2 & 0.1 \\
\hline Maximum consumption parameter, $C_{\mathrm{K} 1}$ & 19.4 & 27.1 & 21.5 & 13.6 & 6.9 & 2.8 & 0.9 & 0.1 & -0.1 \\
\hline Maximum consumption parameter, $C_{\mathrm{TO}}$ & 12.6 & 0.0 & -21.4 & -30.7 & -27.3 & -19.6 & -12.8 & -7.8 & -4.7 \\
\hline Maximum consumption parameter, $C_{\mathrm{TM}}$ & 0.0 & 0.1 & 0.2 & 0.3 & 0.6 & 1.2 & 2.0 & 3.5 & 6.0 \\
\hline Maximum consumption parameter, $C_{\mathrm{TL}}$ & $*$ & $*$ & $*$ & $*$ & $*$ & $*$ & $*$ & 66.7 & 0.0 \\
\hline Maximum consumption parameter, $C_{\mathrm{K} 4}$ & 0.0 & -0.1 & -0.1 & -0.2 & -0.3 & -0.5 & -0.7 & -0.7 & 0.0 \\
\hline Prey length:width ratio & 0.0 & 0.2 & 1.0 & 2.8 & 4.1 & 4.8 & 5.0 & 4.9 & 4.5 \\
\hline Prey dry weight ratio & -14.5 & -27.7 & -34.0 & -39.1 & -42.0 & -43.9 & -45.3 & -46.7 & -48.0 \\
\hline Prey energy density & 11.6 & 26.8 & 33.3 & 38.6 & 41.9 & 43.9 & 45.4 & 46.5 & 47.4 \\
\hline Salmon dry weight constant, $D W_{\mathrm{a}}$ & 14.7 & 25.6 & 31.4 & 36.2 & 40.1 & 42.8 & 44.5 & 45.7 & 46.7 \\
\hline Salmon dry weight coefficient, $D W_{\mathrm{b}}$ & 1.8 & 1.5 & 1.1 & 0.8 & 0.7 & 0.7 & 0.7 & 0.7 & 0.7 \\
\hline
\end{tabular}




\begin{tabular}{|c|c|c|c|c|c|c|c|c|c|}
\hline Egestion scale, $F_{\mathrm{a}}$ & -10.9 & -12.3 & -13.4 & -14.4 & -15.3 & -15.7 & -15.8 & -15.7 & -15.5 \\
\hline Egestion-temperature coefficient, $F_{\mathrm{b} 1}$ & -1.7 & -3.8 & -5.4 & -6.7 & -7.8 & -8.7 & -9.3 & -9.7 & -10.0 \\
\hline Egestion-consumption coefficient, $F_{\mathrm{b} 2}$ & -6.9 & -7.8 & -8.5 & -9.1 & -9.7 & -9.9 & -10.0 & -9.9 & -9.8 \\
\hline Excretion scale, $U_{\mathrm{a}}$ & -0.9 & -1.8 & -2.7 & -3.7 & -4.7 & -5.6 & -6.3 & -7.0 & -7.6 \\
\hline Excretion-temperature coefficient, $U_{\mathrm{b} 1}$ & -0.4 & -1.5 & -2.9 & -4.5 & -6.4 & -8.2 & -9.9 & -11.5 & -13.1 \\
\hline Excretion-consumption coefficient, $U_{\mathrm{b} 2}$ & -0.3 & -0.5 & -0.8 & -1.1 & -1.4 & -1.7 & -1.9 & -2.1 & -2.3 \\
\hline Specific Dynamic Action proportion & -4.1 & -5.7 & -7.0 & -8.1 & -9.0 & -9.7 & -10.1 & -10.3 & -10.4 \\
\hline Burst speed constant & -2.7 & -6.6 & -13.3 & -20.8 & -25.9 & -27.8 & -27.1 & -24.6 & -20.9 \\
\hline Burst speed-temperature coefficient & -0.1 & -0.4 & -1.3 & -2.8 & -4.5 & -5.8 & -6.7 & -7.1 & -7.0 \\
\hline Burst speed-length-temperature constant & 6.1 & 20.8 & 32.4 & 42.8 & 49.3 & 51.7 & 50.4 & 46.2 & 39.7 \\
\hline $\begin{array}{l}\text { Burst speed-length-temperature } \\
\text { coefficient }\end{array}$ & 0.1 & 0.3 & 0.8 & 1.6 & 2.3 & 3.0 & 3.5 & 3.8 & 4.0 \\
\hline Respiration scale, $R_{\mathrm{a}}$ & -15.3 & -18.3 & -19.1 & -20.7 & -22.6 & -24.3 & -25.8 & -27.3 & -28.7 \\
\hline Resp.-temperature coefficient, $R_{\mathrm{b} 1}$ & -23.5 & -58.9 & -86.1 & -105.5 & $*$ & * & * & $*$ & * \\
\hline Resp.-speed coefficient, $R_{\mathrm{b} 2}$ & -15.8 & -29.5 & -41.8 & -56.4 & -68.6 & -76.7 & -81.3 & -83.6 & -84.1 \\
\hline Resp.-weight-temperature power, $R_{\mathrm{b} 3}$ & -0.8 & -1.8 & -3.4 & -5.5 & -8.2 & -10.9 & -13.7 & -16.5 & -19.3 \\
\hline Resp.-weight-speed power, $R_{\mathrm{b} 4}$ & -5.8 & -8.5 & -13.8 & -21.4 & -28.6 & -33.9 & -37.4 & -39.0 & -38.9 \\
\hline Resp.-temperature-speed coefficient, $R_{\mathrm{b} 5}$ & -23.9 & & $*$ & $*$ & $*$ & $*$ & $*$ & $*$ & $*$ \\
\hline Defended reserve ratio, $\lambda_{\text {def }}$ & -0.5 & -0.7 & -0.7 & -0.8 & -0.9 & -1.0 & -1.0 & -1.0 & -1.0 \\
\hline Allocation switch width, $\lambda_{\text {switch }}$ & 0.0 & 0.0 & 0.0 & 0.0 & 0.0 & 0.0 & 0.0 & 0.0 & 0.0 \\
\hline Maximum proportion to structure, $\kappa_{\max }$ & 2.5 & 9.8 & 12.8 & 15.1 & 16.9 & 18.0 & 18.4 & 18.3 & 17.8 \\
\hline Length-structure scale, $L_{0}$ & 10.5 & 41.0 & 51.9 & 60.5 & 66.7 & 70.1 & 71.2 & 70.9 & 69.3 \\
\hline Length-structure power, $\alpha$ & * & * & * & * & * & $*$ & $*$ & $*$ & $*$ \\
\hline Weight-length-energy scale, $W_{0}$ & -4.0 & -2.7 & -0.5 & 0.6 & 1.2 & 1.5 & 1.4 & 1.1 & 0.8 \\
\hline Weight-length power, $\beta$ & 6.1 & 4.5 & 1.4 & 0.0 & -0.7 & -0.9 & -0.8 & -0.6 & -0.3 \\
\hline Weight-energy power, $\gamma$ & $*$ & $*$ & * & * & $*$ & * & $*$ & $*$ & $*$ \\
\hline
\end{tabular}


Table 6. Sensitivity of simulation results to variation in the model parameters at different swimming speeds and a sea surface temperature of $10^{\circ} \mathrm{C}$. Difference in final salmon length between that obtained with a $25 \%$ increase in the default parameter value and that obtained with a $25 \%$ decrease, expressed as a percentage of the final length obtained with the default parameter value. Asterisks indicate cases in which the simulated salmon reached zero energy reserves (bioenergetic 'death') during simulations with altered parameter values.

\begin{tabular}{|c|c|c|c|c|c|c|c|c|c|}
\hline \multirow{2}{*}{ Parameter } & \multicolumn{9}{|c|}{ Swimming speed (body lengths $\mathrm{s}^{-1}$ ) } \\
\hline & 0.50 & 0.75 & 1.00 & 1.25 & 1.50 & 1.75 & 2.00 & 2.25 & 2.50 \\
\hline Initial fish length & 8.8 & 8.2 & 7.3 & 6.3 & 5.2 & 4.0 & 3.0 & 2.1 & 1.3 \\
\hline Initial weight-length scale & 2.5 & 2.2 & 1.8 & 1.3 & 0.7 & 0.0 & -0.8 & -1.7 & -2.9 \\
\hline Initial weight-length power & * & * & * & $*$ & $*$ & $*$ & $*$ & $*$ & $*$ \\
\hline Minimum swimming speed & -1.4 & -1.4 & -1.4 & -1.4 & -1.4 & -1.5 & -1.5 & -1.5 & -1.5 \\
\hline Maximum swimming speed & 0.0 & 0.0 & 0.0 & 0.0 & 0.0 & 0.0 & 0.0 & 0.0 & 0.0 \\
\hline Minimum edible prey size & -0.2 & -0.2 & -0.2 & -0.3 & -0.3 & -0.3 & -0.2 & -0.1 & -0.1 \\
\hline Maximum edible prey size & 6.7 & 6.4 & 5.9 & 5.1 & 4.1 & 3.1 & 2.1 & 1.4 & 0.8 \\
\hline Feeding time & 0.0 & 0.0 & 0.0 & 0.0 & 0.0 & 0.0 & 0.0 & 0.0 & 0.0 \\
\hline Zooplankton density & -0.9 & -1.0 & -1.0 & -1.1 & -1.4 & -1.7 & -1.8 & -1.8 & -1.7 \\
\hline Zooplankton 'lost' to higher predators & -0.1 & -0.1 & -0.1 & -0.1 & -0.1 & -0.1 & -0.1 & -0.1 & -0.1 \\
\hline Reaction distance scale, $D_{\mathrm{a}}$ & -3.3 & -3.3 & -3.3 & -3.2 & -3.0 & -2.7 & -2.4 & -2.0 & -1.6 \\
\hline Reaction distance power, $D_{\mathrm{b}}$ & 0.1 & 0.1 & 0.1 & 0.1 & 0.1 & 0.2 & 0.2 & 0.2 & 0.2 \\
\hline Prey handling time & 0.0 & 0.0 & 0.0 & 0.0 & 0.0 & 0.0 & 0.0 & 0.0 & 0.0 \\
\hline Maximum consumption scale, $C_{\mathrm{A}}$ & 41.5 & 41.3 & 40.9 & 40.1 & 38.9 & 37.4 & 35.9 & 34.3 & 32.8 \\
\hline Maximum consumption parameter, $C_{\mathrm{B}}$ & 65.9 & 65.3 & 63.9 & 61.5 & 58.0 & 53.8 & 49.1 & 44.4 & 39.9 \\
\hline Maximum consumption parameter, $C_{\mathrm{Q}}$ & -8.0 & -8.0 & -7.9 & -7.7 & -7.5 & -7.2 & -6.9 & -6.6 & -6.3 \\
\hline Maximum consumption parameter, $C_{\mathrm{K} 1}$ & 7.0 & 7.0 & 6.9 & 6.8 & 6.5 & 6.3 & 6.1 & 5.8 & 5.5 \\
\hline Maximum consumption parameter, $C_{\mathrm{TO}}$ & -27.8 & -27.7 & -27.3 & -26.7 & -25.9 & -24.9 & -23.8 & -22.8 & -21.7 \\
\hline Maximum consumption parameter, $C_{\mathrm{TM}}$ & 0.7 & 0.6 & 0.6 & 0.6 & 0.6 & 0.6 & 0.6 & 0.5 & 0.5 \\
\hline Maximum consumption parameter, $C_{\mathrm{TL}}$ & $*$ & $*$ & $*$ & $*$ & $*$ & $*$ & $*$ & $*$ & $*$ \\
\hline Maximum consumption parameter, $C_{\mathrm{K} 4}$ & -0.3 & -0.3 & -0.3 & -0.3 & -0.3 & -0.3 & -0.3 & -0.3 & -0.3 \\
\hline Prey length:width ratio & 4.3 & 4.2 & 4.1 & 3.9 & 3.5 & 2.9 & 2.1 & 1.3 & 0.8 \\
\hline Prey dry weight ratio & -41.7 & -41.9 & -42.0 & -41.9 & -41.3 & -40.0 & -38.1 & -36.1 & -34.1 \\
\hline Prey energy density & 41.7 & 41.9 & 41.9 & 41.7 & 41.0 & 39.6 & 37.8 & 35.8 & 33.8 \\
\hline Salmon dry weight constant, $D W_{\mathrm{a}}$ & 40.7 & 40.6 & 40.1 & 39.3 & 38.0 & 36.5 & 34.9 & 33.2 & 31.5 \\
\hline Salmon dry weight coefficient, $D W_{\mathrm{b}}$ & 0.7 & 0.7 & 0.7 & 0.7 & 0.8 & 0.8 & 0.8 & 0.9 & 1.1 \\
\hline Egestion scale, $F_{\mathrm{a}}$ & -15.5 & -15.5 & -15.3 & -14.9 & -14.4 & -13.8 & -13.2 & -12.5 & -11.9 \\
\hline
\end{tabular}


Egestion-temperature coefficient, $F_{\mathrm{b} 1}$ Egestion-consumption coefficient, $F_{\mathrm{b} 2}$ Excretion scale, $U_{\mathrm{a}}$

Excretion-temperature coefficient, $U_{\mathrm{b} 1}$

Excretion-consumption coefficient, $U_{\mathrm{b} 2}$ Specific Dynamic Action proportion

Burst speed constant

Burst speed-temperature coefficient

Burst speed-length-temperature constant

Burst speed-length-temperature coefficient

Respiration scale, $R_{\mathrm{a}}$

Resp.-temperature coefficient, $R_{\mathrm{b} 1}$

Resp.-speed coefficient, $R_{\mathrm{b} 2}$

Resp.-weight-temperature power, $R_{\mathrm{b} 3}$

Resp.-weight-speed power, $R_{\mathrm{b} 4}$

Resp.-temperature-speed coefficient, $R_{\mathrm{b} 5}$

Defended reserve ratio, $\lambda_{\text {def }}$

Allocation switch width, $\lambda_{\text {switch }}$

Maximum proportion to structure, $\kappa_{\max }$

Length-structure scale, $L_{0}$

Length-structure power, $\alpha$

Weight-length-energy scale, $W_{0}$

Weight-length power, $\beta$

Weight-energy power, $\gamma$

\begin{tabular}{|c|c|c|c|c|c|c|c|c|}
\hline-8.0 & -7.9 & -7.8 & -7.7 & -7.4 & -7.1 & -6.8 & -6.4 & -6.1 \\
\hline-9.9 & -9.8 & -9.7 & -9.5 & -9.1 & -8.8 & -8.4 & -7.9 & -7.5 \\
\hline-4.8 & -4.7 & -4.7 & -4.6 & -4.4 & -4.2 & -4.0 & -3.8 & -3.6 \\
\hline-6.5 & -6.4 & -6.4 & -6.2 & -6.0 & -5.7 & -5.5 & -5.2 & -4.9 \\
\hline-1.4 & -1.4 & -1.4 & -1.4 & -1.3 & -1.3 & -1.2 & -1.1 & -1.1 \\
\hline-9.2 & -9.1 & -9.0 & -8.8 & -8.5 & -8.2 & -7.8 & -7.4 & -7.0 \\
\hline-27.3 & -26.8 & -25.9 & -24.6 & -22.7 & -20.4 & -17.7 & -14.8 & -12.0 \\
\hline-4.5 & -4.5 & -4.5 & -4.3 & -4.1 & -3.7 & -3.2 & -2.7 & -2.2 \\
\hline 50.6 & 50.2 & 49.3 & 48.0 & 46.0 & 43.3 & 40.1 & 36.4 & 32.4 \\
\hline 2.2 & 2.3 & 2.3 & 2.4 & 2.3 & 2.2 & 2.0 & 1.7 & 1.5 \\
\hline-17.1 & -19.8 & -22.6 & -25.3 & -27.9 & -30.0 & -31.6 & -32.5 & -32.7 \\
\hline-104.5 & $*$ & $*$ & $*$ & $*$ & $*$ & $*$ & $*$ & $*$ \\
\hline-63.2 & -65.6 & -68.6 & -72.3 & -76.7 & -81.5 & -86.8 & -89.7 & -90.6 \\
\hline-6.4 & -7.3 & -8.2 & -8.9 & -9.5 & -9.8 & -9.9 & -9.6 & -9.1 \\
\hline-24.6 & -26.5 & -28.6 & -30.6 & -32.6 & -34.2 & -35.5 & -36.1 & -36.1 \\
\hline$*$ & $*$ & $*$ & $*$ & $*$ & $*$ & * & $*$ & $*$ \\
\hline-1.0 & -1.0 & -0.9 & -0.9 & -0.8 & -0.8 & -0.7 & -0.6 & -0.6 \\
\hline 0.0 & 0.0 & 0.0 & 0.0 & 0.0 & 0.0 & 0.0 & 0.0 & 0.0 \\
\hline 18.4 & 17.7 & 16.9 & 15.9 & 14.7 & 13.4 & 12.1 & 10.9 & 9.7 \\
\hline 71.9 & 69.7 & 66.7 & 63.0 & 58.7 & 53.9 & 49.0 & 44.3 & 39.7 \\
\hline$*$ & $*$ & $*$ & $*$ & $*$ & $*$ & $*$ & $*$ & $*$ \\
\hline 7.2 & 4.4 & 1.2 & -2.0 & -5.2 & -8.0 & -10.2 & -11.7 & -12.3 \\
\hline-5.7 & -3.4 & -0.7 & 2.4 & 5.5 & 8.4 & 11.0 & 12.9 & 14.1 \\
\hline$*$ & * & $*$ & $*$ & * & * & $*$ & $*$ & $*$ \\
\hline
\end{tabular}


Table 7. Comparison of simulated and published values of specific growth rate (SGR) and thermal-unit growth coefficient (TGC) under different conditions of initial body weight, temperature and swimming speed.

\begin{tabular}{|c|c|c|c|c|c|}
\hline \multirow{2}{*}{$\begin{array}{l}\text { Initial } \\
\text { weight } \\
\text { (g) }\end{array}$} & \multirow{2}{*}{$\begin{array}{c}\text { Temperature } \\
\left({ }^{\circ} \mathrm{C}\right)\end{array}$} & \multicolumn{2}{|c|}{ SGR at speed } & \multirow{2}{*}{$\begin{array}{l}\text { Published } \\
\text { value }\end{array}$} & \multirow[t]{2}{*}{ Reference } \\
\hline & & $0.5 \mathrm{bl} \mathrm{s}^{-1}$ & $1.0 \mathrm{bl} \mathrm{s}^{-1}$ & & \\
\hline \multirow[t]{5}{*}{61} & 4.3 & 0.342 & 0.225 & 0.274 & Handeland et al. (2003) \\
\hline & 9.4 & 1.196 & 1.072 & 0.723 & \\
\hline & 14.3 & 1.515 & 1.384 & 0.989 & \\
\hline & \multicolumn{3}{|c|}{ TGC at speed } & & \\
\hline & & $0.5 \mathrm{bl} \mathrm{s}^{-1}$ & $1.0 \mathrm{bl} \mathrm{s}^{-1}$ & & \\
\hline 528 & 9.0 & $1.41 \times 10^{-3}$ & $9.57 \times 10^{-4}$ & $1.39 \times 10^{-3}$ & Thodesen et al. (1999) \\
\hline
\end{tabular}

